\title{
Carbon and oxygen isotope compositions of the carbonate facies in the Vindhyan Supergroup, central India
}

\author{
S BANERJEE ${ }^{1}$, S K BHATtACHARYA ${ }^{2}$ and S SARKAR ${ }^{3}$ \\ ${ }^{1}$ Department of Earth Sciences, Indian Institute of Technology Bombay, Powai, Mumbai 400 076, India. \\ ${ }^{2}$ Physical Research Laboratory, Navrangpura, Ahmedabad 380 009, India. \\ ${ }^{3}$ Department of Geological Sciences, Jadavpur University, Kolkata 700 032, India.
}

The Vindhyan sedimentary succession in central India spans a wide time bracket from the Paleoproterozoic to the Neoproterozoic period. Chronostratigraphic significance of stable carbon and oxygen isotope ratios of the carbonate phase in Vindhyan sediments has been discussed in some recent studies. However, the subtle controls of facies variation, depositional setting and post-depositional diagenesis on stable isotope compositions are not yet clearly understood. The Vindhyan Supergroup hosts four carbonate units, exhibiting a wide variability in depositional processes and paleogeography. A detailed facies-specific carbon and oxygen isotope study of the carbonate units was undertaken by us to investigate the effect of these processes and to identify the least altered isotope values. It is seen that both carbon and oxygen isotope compositions have been affected by early meteoric water diagenesis. The effect of diagenetic alteration is, however, more pronounced in case of oxygen isotopes than carbon isotopes. Stable isotope compositions remained insensitive to facies only when sediments accumulated in a shallow shelf setting without being exposed. Major alteration of original isotope ratios was observed in case of shallow marine carbonates, which became exposed to meteoric fluids during early diagenetic stage. Duration of exposure possibly determined the magnitude of alteration and shift from the original values. Moreover, dolomitization is found to be accompanied by appreciable alteration of isotope compositions in some of the carbonates. The present study suggests that variations in sediment depositional settings, in particular the possibility of subaerial exposure, need to be considered while extracting chronostratigraphic significance from $\delta^{13} \mathrm{C}$ data.

\section{Introduction}

Carbon and oxygen isotope data of Precambrian carbonates harbour a wealth of information on past hydrospheres, atmospheres and biospheres (Veizer et al 1980, 1999; Beeunas and Knauth 1985). Carbon isotopes have provided a useful tool for correlation of end-Precambrian sedimentary successions of the world (Veizer et al 1992; Des Marais 1994; Knoll et al 1995; Hall and Veizer 1996; Frank et al 1997; Lindsay and Brasier 2000; Shields and Veizer 2002; Ray et al 2003). A common assumption of all the studies mentioned above is that both carbon and oxygen isotopes are insensitive to sedimentary facies (see also Knoll et al 1986; Kaufman and Knoll 1995). Carbon and oxygen isotope analyses have been performed on the Proterozoic Vindhyan carbonates and their chronostratigraphic significance have been discussed in many recent studies (Friedman et al 1996, 2004; Friedman and Chakraborty 1997; Kumar et al 2002; Ray et al 2003). Ray et al (2003) provided detailed carbon, oxygen and strontium isotope systematics of the Vindhyan carbonates, discussed secular variation of these isotopes and presented primary carbon and oxygen isotope values. Most of these studies recorded average Paleoproterozoic to Neoproterozoic carbon and oxygen isotope values

Keywords. Facies; meteoric water; diagenesis; Vindhyan; Proterozoic.

J. Earth Syst. Sci. 115, No. 1, February 2006, pp. 113-134

(C) Printed in India. 


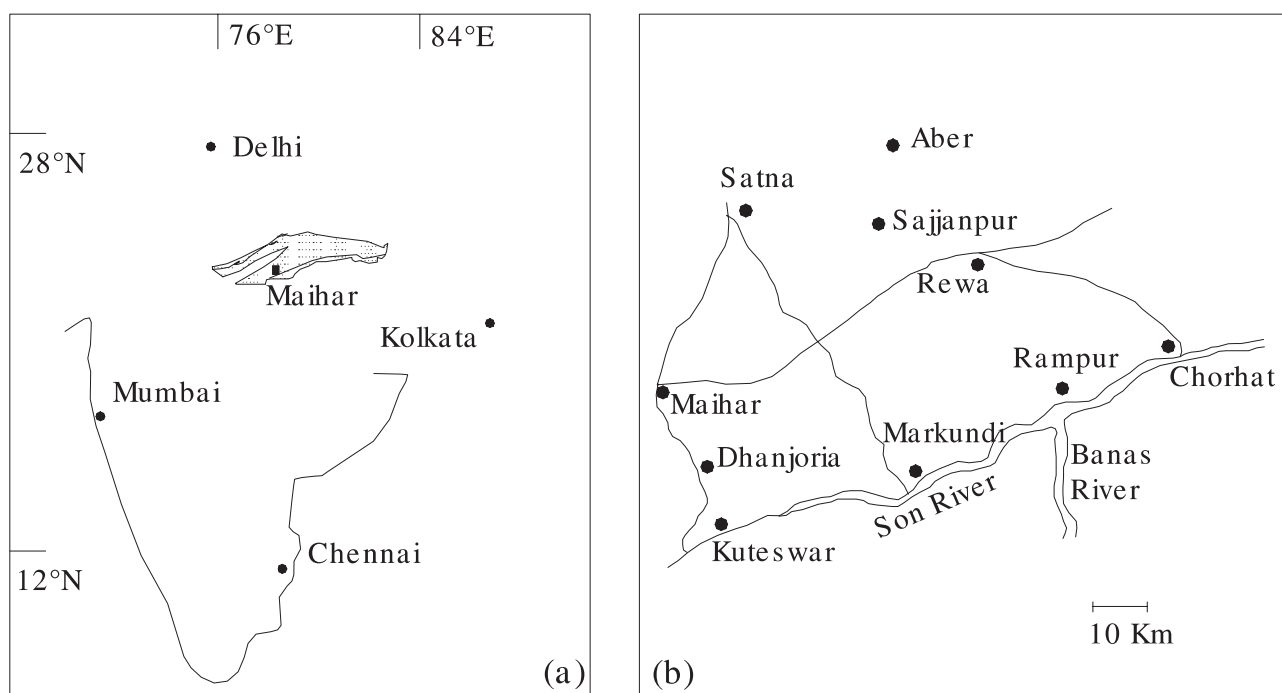

Figure 1. Map of India showing outcrop distribution of the Vindhyan basin in the Son valley area (a) and location map of the study area (b). Location of Maihar is common in both the figures.

from the Vindhyan Supergroup. None of the abovementioned studies, however, discussed isotope compositions of the Vindhyan carbonates in relation to the carbonate facies. Samples for the studies were selected ignoring facies and paleogeography of the constituent carbonate units, which could have influenced isotope compositions. A few studies, however, considered carbonate facies while interpreting the stable carbon and oxygen isotope data (Banerjee 1997; Sarkar et al 1998; Chakraborty et al 2002; Chakraborty 2004; Banerjee et al 2005). Sarkar et al (1998) and Chakraborty et al (2002) recorded facies sensitivity of Neoproterozoic Bhander Limestone. In this context, it is appropriate to investigate the depositional and diagenetic controls on stable isotope compositions of the Vindhyan carbonates in detail.

The present paper discusses stable isotope compositions of the Vindhyan carbonates in relation to the sedimentary facies and paleogeography to understand depositional and diagenetic influences on the stable isotope compositions of all the carbonate units of the Vindhyan Supergroup. The study attempts to compare chronostratigraphic versus depositional/diagenetic controls on stable isotope compositions of the Vindhyan carbonates.

\section{Geological background and age constraints}

The Vindhyan succession of central India is twotiered, about $4500 \mathrm{~m}$ thick and consists of mildly deformed and un-metamorphosed siliciclastics and carbonates exposed over wide areas in central India (figure 1). The Semri Group comprises of siliciclastics, carbonates and volcaniclastics (figure 2). The Kajrahat Limestone and the Rohtas Limestone are the two important carbonate units of the Semri Group (figure 2). A thin, discontinuous dolomite unit occurs at the mid-level of the predominantly siliciclastic Kheinjua Formation and is known as the Fawn Dolomite. The Upper Vindhyan Group is dominated by clastics and the sole carbonate unit, the Bhander Limestone occurs near the top of the succession (figure 2). Preservation of delicate sedimentary features is a distinct characteristic of the entire Vindhyan succession. Detailed facies analysis is thus possible on all the carbonate units of the Vindhyan Supergroup. Excellent preservation of sedimentary features, dominantly micritic nature of the carbonate sediments and lack of compaction features rule out significant burial diagenesis of the carbonates (Bose et al 2001; Chakraborty 2004). Vindhyan sedimentation took place largely in a shallow marine setting (Chanda and Bhattacharyya 1982; Bose et al 2001), although minor paleogeographic shifts have been reported in a few recent studies (Chakraborty 2004; Banerjee et al 2005). It is believed that the initial sedimentation took place in an intracratonic rift basin and then a transition to intracratonic sag basin took place during the upper Vindhyan.

On the basis of ${ }^{87} \mathrm{Sr} /{ }^{86} \mathrm{Sr}$ ratios the age of the oldest carbonate unit, namely the Kajrahat Limestone, is assumed to be $1700 \mathrm{Ma}$ old (Ray et al 2003). Rasmussen et al (2002) and Ray et al (2002) determined the age of the overlying Porcellanite Formation to be $1630 \mathrm{Ma}$ by U/Pb SHRIMP dating technique. Sarangi et al (2004) determined an age of $1600 \mathrm{Ma}$ age for the Rohtas Limestone. The age of the Fawn Dolomite is, therefore, between 1630 


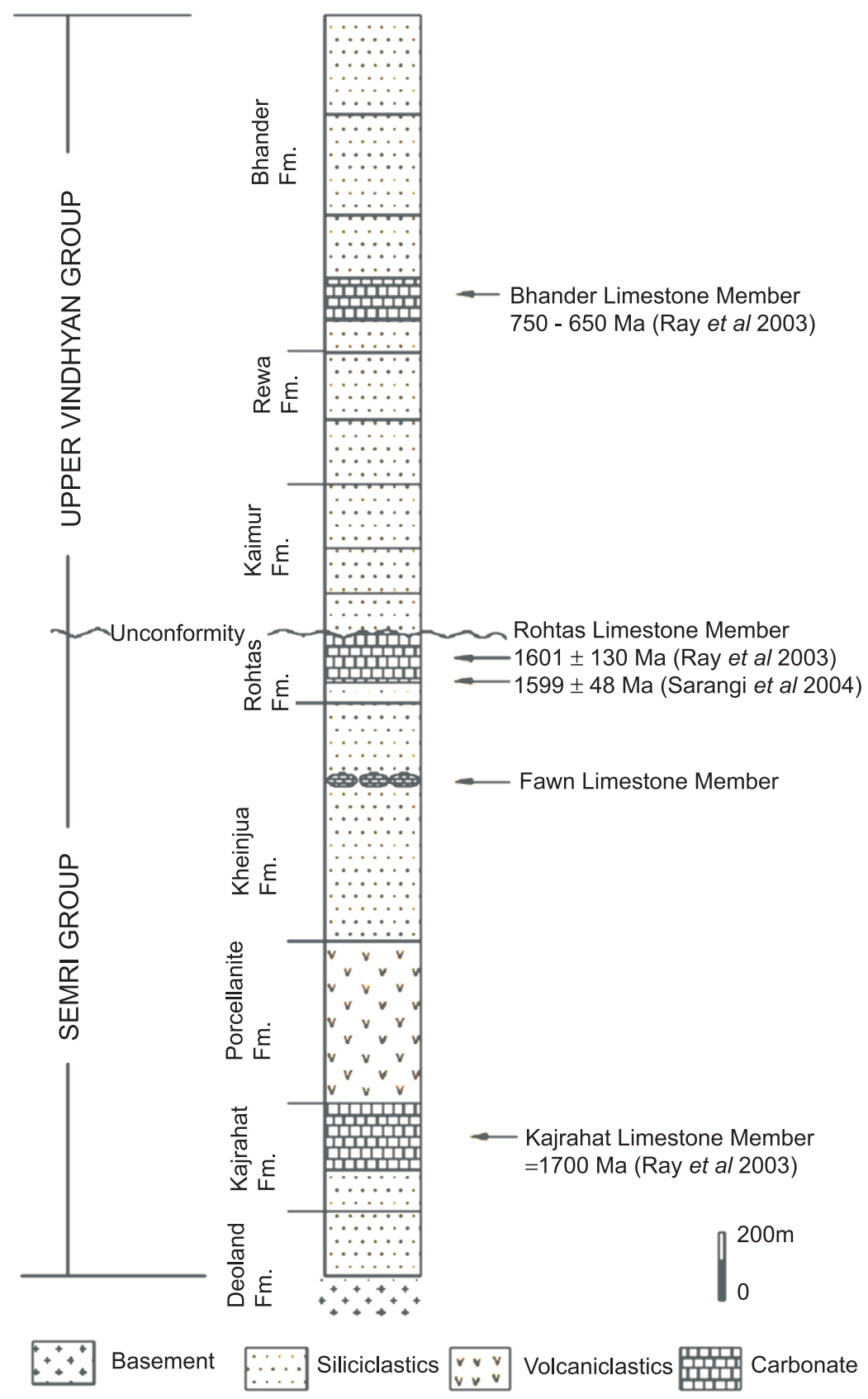

Figure 2. Vertical section showing details of the Vindhyan stratigraphy up to the formation level highlighting the four carbonate units (modified after Bose et al 2001). Ages of the carbonate units (after Ray et al 2003) are provided on the right of the vertical section.

and $1600 \mathrm{Ma}$. These data are consistent with those obtained by Rasmussen et al (2002) for the ash tuff unit at the base of the Rohtas Formation. The age of the Bhander Limestone is not precisely determined, but most likely it brackets an age range between 650 and $750 \mathrm{Ma}$ (Ray et al 2003).

\section{Samples and methods}

The constituent facies of the four carbonate units of the Vindhyan Supergroup have been documented in the Son valley area of Madhya Pradesh through detailed field and petrographic observations carried out over a decade, the results of which have been presented partially elsewhere (Sarkar et al 1996, 1998; Banerjee 1997; Bose et al 2001; Chakraborty 2004; Banerjee et al 2005). In this paper we have presented relatively detailed facies description for the Semri Group as only a few studies provide such information. Fresh samples were collected for isotope analysis from all four of the carbonate units of the Vindhyan Supergroup while noting their respective 


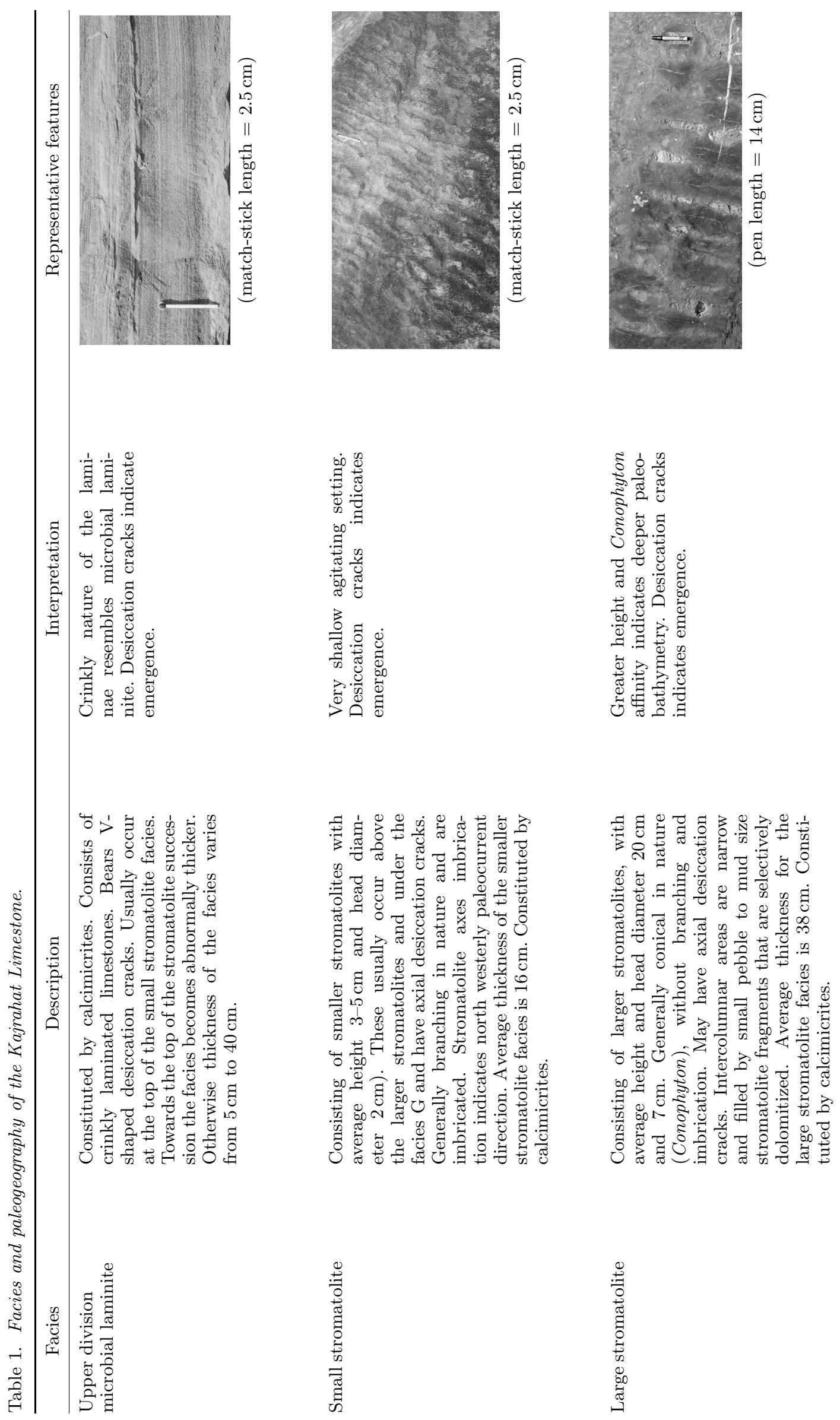


Carbon and oxygen isotope compositions
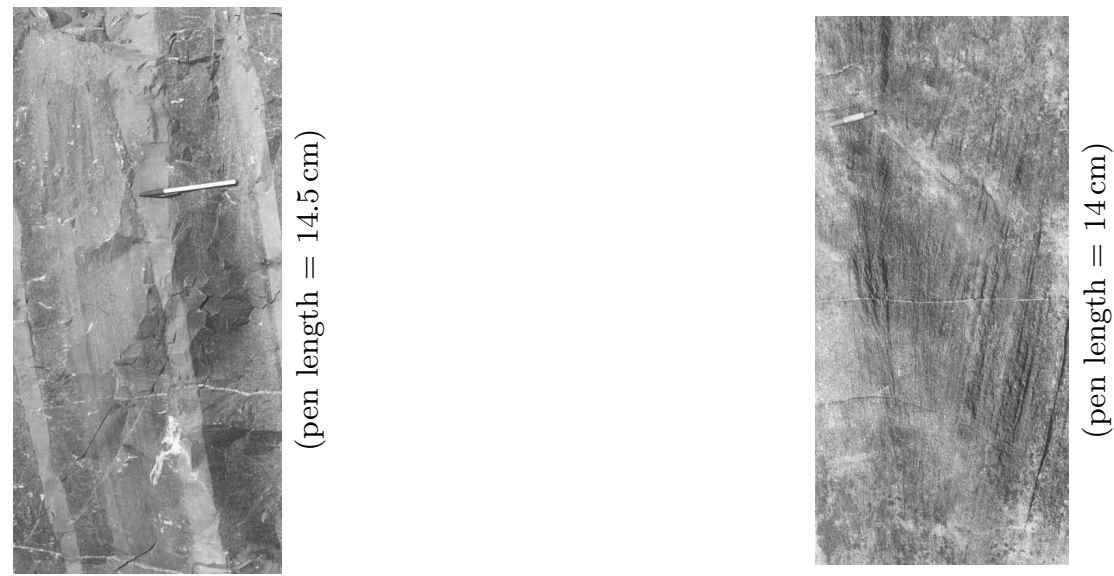

0
0
0
0
0
0
0
0
0
0
0
0
0
70
00
0
0
0
0
0
0
0
0
0
0
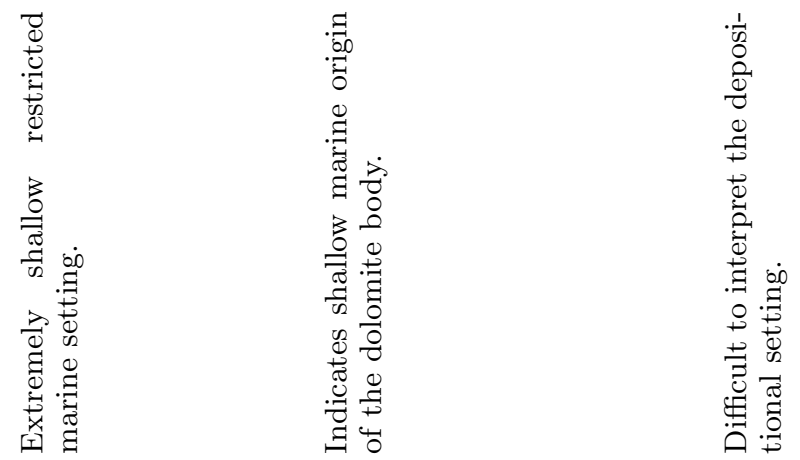

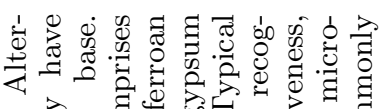

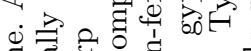

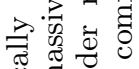

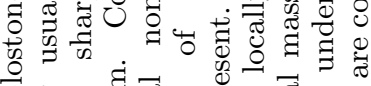

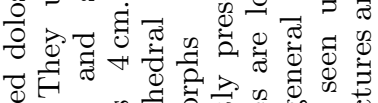

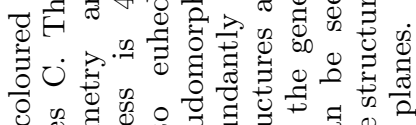

○.

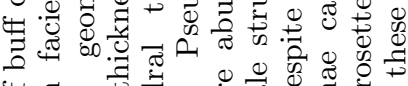

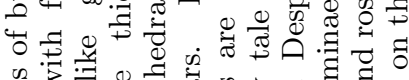

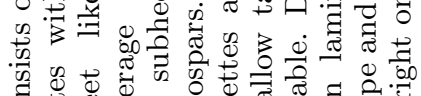

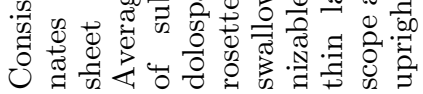

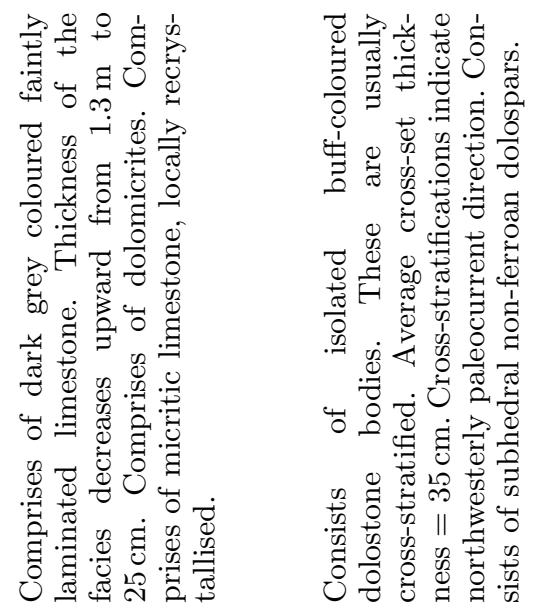

융 $\frac{1}{0}$
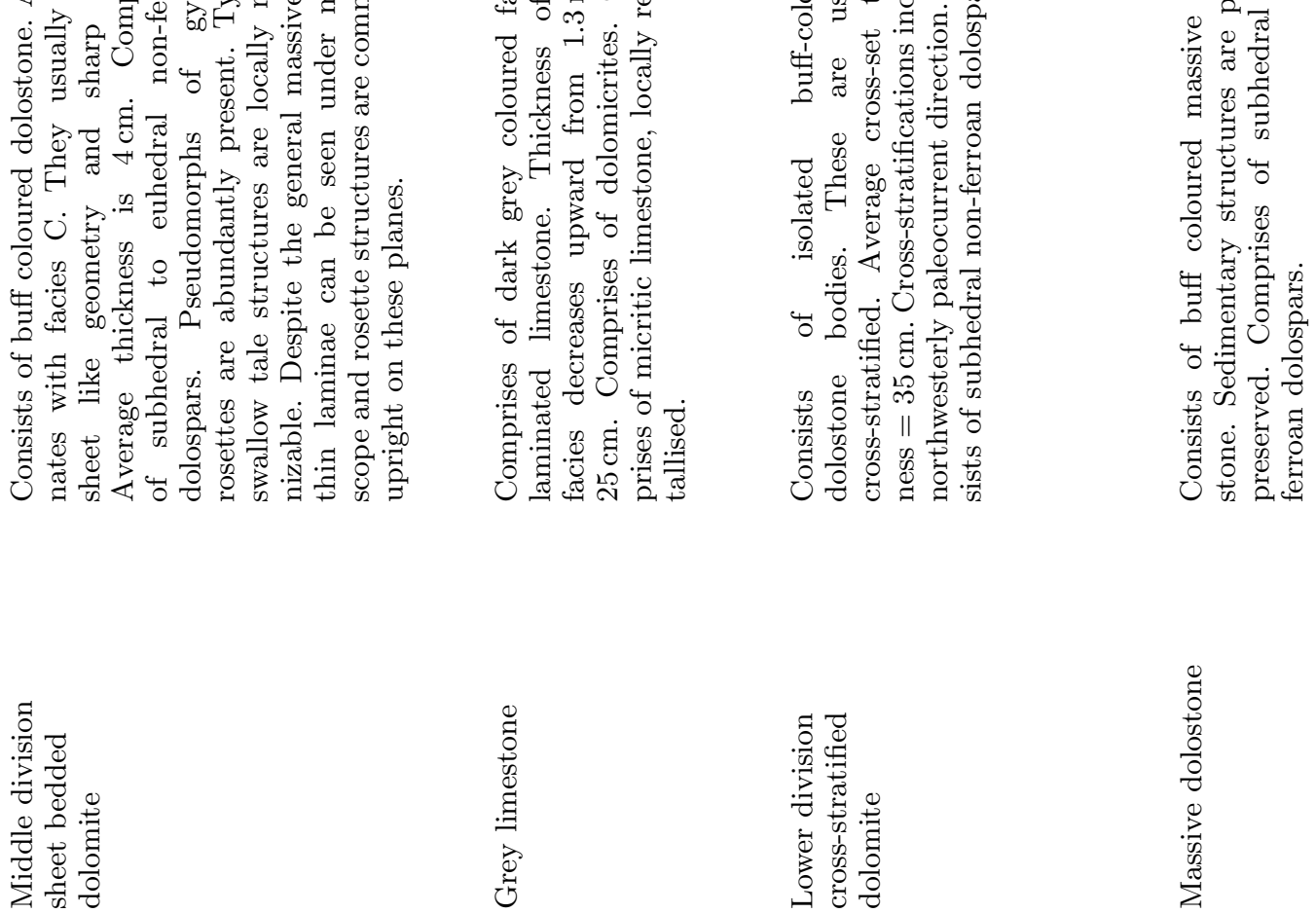


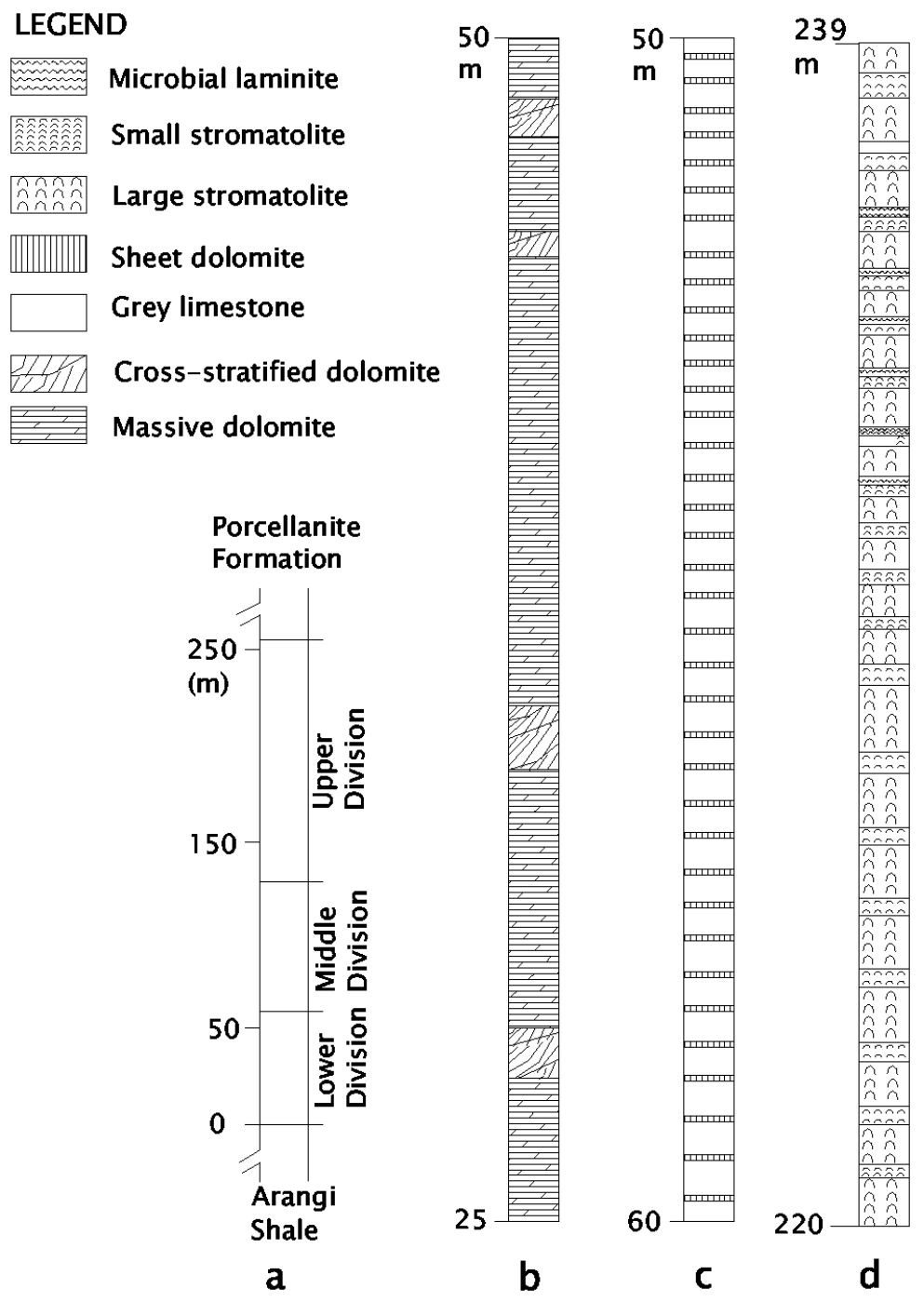

Figure 3. Vertical section showing three divisions of the Kajrahat Limestone in the Son valley area (a). Logs showing constituent facies of the lower division (b), middle division (c) and upper division (d). The given height in b, c and d corresponds to the stratigraphic height from the base of the Kajrahat Limestone. Note cyclicity defined by large stromatolite, small stromatolite and algal laminite in the upper division (d).

facies and stratigraphic position. Samples were selected covering the entire stratigraphy of each of the carbonate units. The samples were collected from different locations in the Son valley area (figure 1). 40 samples were collected from the $255 \mathrm{~m}$ thick Kajrahat Limestone section near Kuteshwar area. 26 samples were collected from three sections of Fawn Dolomite around Chorhat, Markundi and Dhanjoria. 31 samples were collected from the Rohtas Limestone section of the Rampur area. 52 samples were collected from several short sections of Bhander Limestone spread over Maihar, Rewa, Aber and Satna and Sajjanpur (figure 1).

Carbon and oxygen isotope analysis of the samples was performed at the Physical Research Laboratory, Ahmedabad. Due care was given to select visibly unaltered micritic carbonate samples identified by prior petrographic studies involving light microscope and SEM. Thin sections of carbonate samples were stained by Dickson's (1966) method. SEM studies were carried out with the help of JEOL JSM 840A Scanning Electron Microscope at IIT Bombay. Samples containing recrystallisation veins, crack-fills and neomorphic calcites were discarded. Chosen samples were cleaned, disaggregated and then powdered. Carbon and oxygen isotopes ratios were measured by treating the powdered samples with $\mathrm{H}_{3} \mathrm{PO}_{4}$ at $50^{\circ} \mathrm{C}$ for 10 minutes, cleaning the evolved $\mathrm{CO}_{2}$ from water vapour and other condensable gases and analysing it in a VG Micromass 903 triple collector mass spectrometer. The isotopic ratios $\delta^{13} \mathrm{C}$ and $\delta^{18} \mathrm{O}$ are expressed with respect to the international standard PDB (Craig 1957) and are reproducible to $\pm 0.1 \%$ at $1 \sigma$ level. Reproducibility measured 


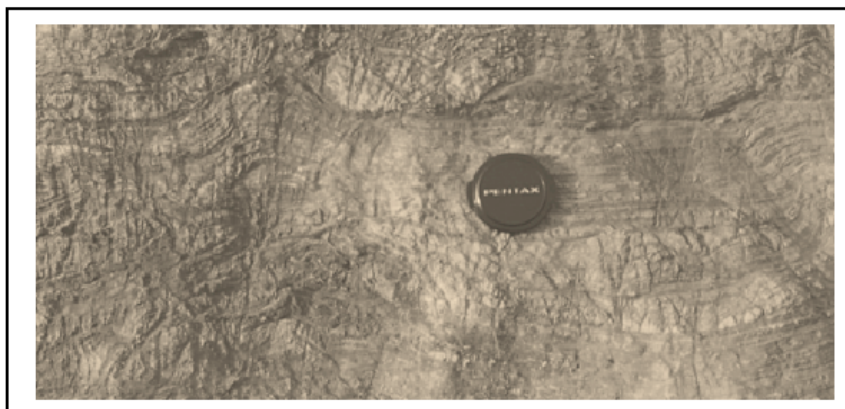

a)

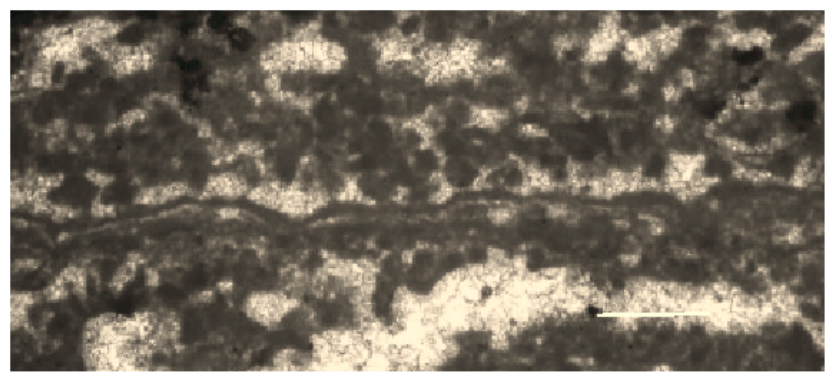

c)

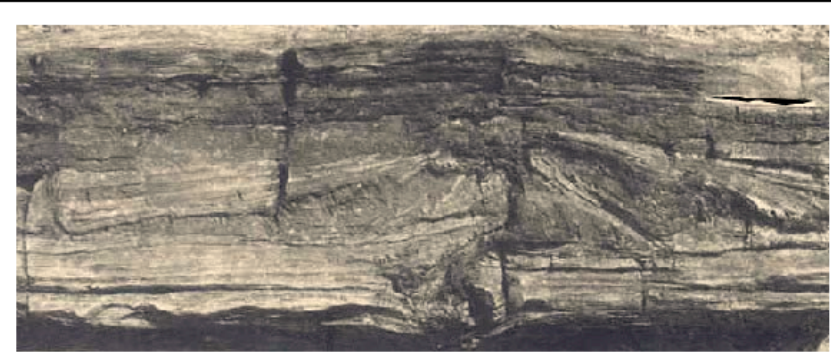

b)

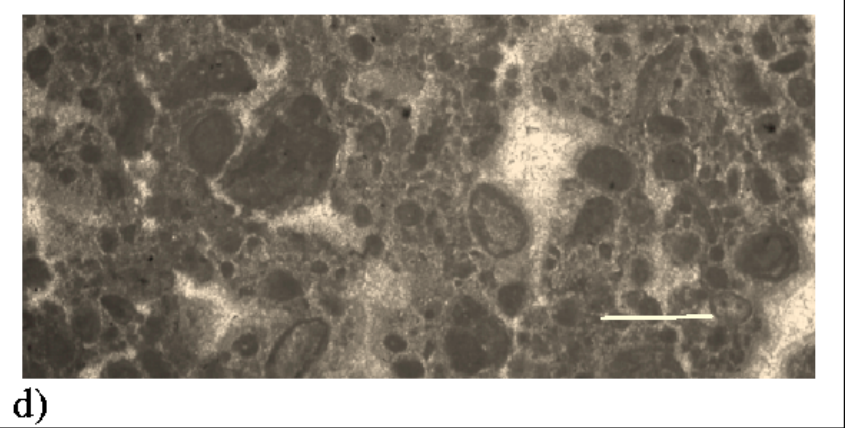

Figure 4. Photographs showing representative features of the Fawn Dolomite: crinkle laminated dolomite (a), tepee structures (b) fenestrae (white patches), (c) and peloids (d). Lens cap diameter $=5 \mathrm{~cm}$, pen length $=14 \mathrm{~cm}$, bar $=0.6 \mathrm{~cm}$.

as $1 \sigma$ for five samples of NBS-19 $\left(\delta^{13} \mathrm{C}=1.95 \%\right.$, $\delta^{18} \mathrm{O}=-2.20 \%$ ) was approximately $0.1 \%$ for both $\delta^{13} \mathrm{C}$ and $\delta^{18} \mathrm{O}$.

\section{Carbonate facies}

Summary of facies analysis of the three major carbonate units are presented in tables 1,2 and 3 . A brief discussion on facies and paleogeography of all four of the carbonate units in the study area (sampling sites) is presented below.

\subsection{Kajrahat Limestone}

The Kajrahat Limestone is up to $255 \mathrm{~m}$ thick in the area around Kuteswar and comprises of three superposed divisions characterized by distinctive facies assemblages (Banerjee 1997; table 1, figure 3). The $60 \mathrm{~m}$-thick basal division is predominantly dolomitic and comprises of massive dolomite facies and cross-stratified dolomite facies. The $70 \mathrm{~m}$-thick middle division is composed of vertical alternations of faintly laminated grey limestone facies and buff coloured sheet-bedded dolomite facies. Under the microscope, the sheet-bedded dolomite reveals pseudomorphs of gypsum rosettes. The $125 \mathrm{~m}$-thick upper division predominantly comprises of large stromatolite facies, small stromatolite facies and microbial laminite facies. The larger stromatolite columns often show the presence of axial vertical cracks caused by desiccation
(Bose et al 2001). Microscopic observation shows that the cracks are filled up by non-ferroan limpid calcispars. The smaller stromatolites, usually imbricated, occur above the larger stromatolites. Microbial laminites usually occur above the small stromatolites and bear V-shaped cracks filled by clear blocky non-ferroan calcite. Regular vertical stacking of large stromatolites, followed by small stromatolites and microbial laminites indicates the presence of a conspicuous sedimentary cyclicity within the Kajrahat Limestone (figure 3). Banerjee (1997) recorded several such cyclicities from the upper division of the Kajrahat Limestone. Despite their variations in form, all these microbial facies are made of non-ferroan calcimicrite, recrystallized locally into non-ferroan calcite microspar to a variable extent.

Extensive dolomitization has erased many of the primary sedimentary features in the lower division of the Kajrahat Limestone creating difficulty in paleogeographic reconstruction. The large-scale cross-stratified bodies possibly represent channelfills. Their distribution in the lower and upper divisions suggests a shallow marine environment of deposition. Presence of oriented stromatolites within the upper division corroborates the hypothesis of shallow marine origin (Hoffman 1976). Occasional extreme shallowing is indicated by gypsum crystals in the sheet bedded dolomite facies, presumably formed at the sediment-water interface. V-shaped cracks within the microbial laminite 


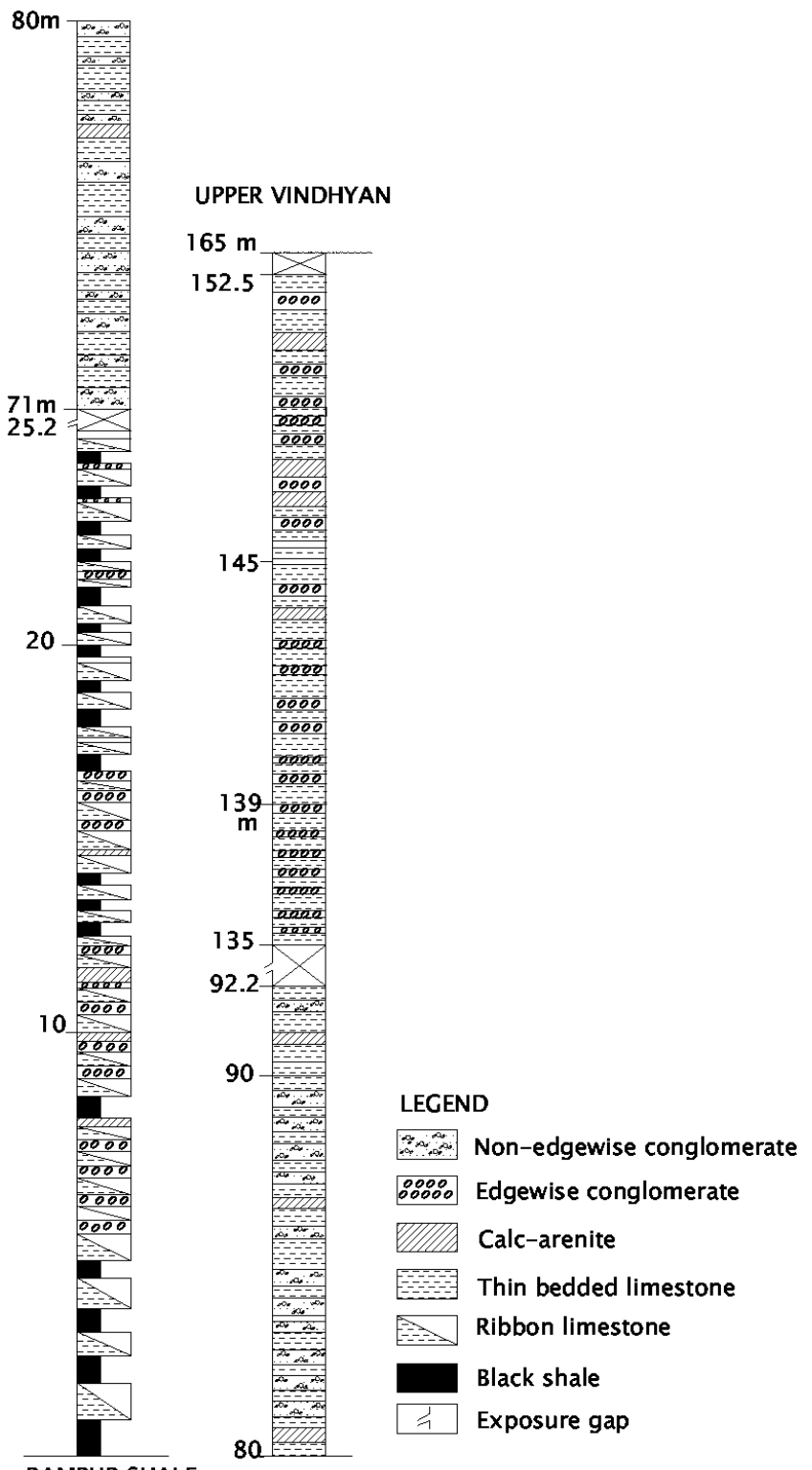

RAMPUR SHALE

Figure 5. Vertical section showing constituent facies of the Rohtas Limestone in the Rampur area.

facies represent desiccation cracks and indicate emergence above the water level. The microbial laminite facies possibly formed in very shallow conditions and represents a supratidal setting. Large stromatolite facies, on the other hand, possibly developed in a deep subtidal setting, beneath fair weather wave base (Grotzinger 1986; Southgate 1989). Smaller stromatolites exhibit consistent orientation indicating strong agitation in a shallow subtidal setting (Hoffman 1976; Grotzinger 1986; Glumac and Walker 1997, 2000). Reduction of stromatolite size is related to shallowing of the basin. Therefore, the periodic alternation of large stromatolite, small stromatolites and microbial laminites within the Kajrahat Limestone indicates cyclic fluctuation in sea level leading to eventual exposure in each cycle. The scale of marine regression was such that it caused repeated exposure of deep subtidal facies (large stromatolite). Obviously, duration of exposure will be more in case of microbial laminites compared to the larger stromatolites.

\subsection{Fawn Dolomite}

Carbonates occur as discontinuous bodies within the predominantly siliciclastic Kheinjua Formation. In the study area, the carbonate unit is restricted in thin (less than $10 \mathrm{~m}$ ) local patches without any formal stratigraphic status (Bose et al 2001). The predominantly dolomitic body known as Fawn Dolomite/Salkhan Limestone in the eastern Son valley (Auden 1933; Prakash and Dalela 1982) comprises almost exclusively of microbial laminite (figure 4; Banerjee 1997) and occurs above the progradational fluvio-deltaic succession of the Koldaha Shale (Bose et al 2001). Tepee structures can be seen at places. Fenestrae and bird's eye features can be seen under the microscope (figure 4). Although it consists of laminated nonferroan dolomicrite, at places (Markundi) it comprises of pelsparite and oosparite (figure 4).

Fenestrae and bird's eye features suggest rotting of microbial mat and subsequent expulsion of microbially generated gases. Tepee structures also suggest collapse of mat cover due to expulsion of gases. The carbonate body sandwiched between siliciclastic strata packages of the Koldaha Shale and the Chorhat Sandstone is considered to be of estuarine origin near Chorhat (Banerjee 1997). The carbonate bodies near Markundi and Dhanjoria possibly have features of lagoonal and supratidal deposits respectively (Banerjee 1997).

\subsection{Rohtas Limestone}

The Rohtas Limestone gradationally overlies the Rampur Shale in the Son valley area. The latter predominantly consists of black shale with thin limestone interbeds $(<3 \mathrm{~cm}$ thick). Rohtas Limestone in the Rampur area comprises of six facies (Banerjee et al 2005; figure 5, table 2) described as: black shale facies, ribbon limestone facies, thinbedded limestone facies, calcarenite facies, flake conglomerate facies and non-edgewise conglomerate facies. Black shale facies alternates with ribbon limestone facies and flake conglomerate facies in the lower parts of the Rohtas Limestone. Middle and upper part of the Rohtas Limestone consist of thin-bedded limestone facies, calc-arenite facies, flake-conglomerate facies and non-edgewise conglomerate facies. Wavy and crinkly laminae are characteristic of the black shale facies (Schieber 1999). The ribbon limestone facies is characterized by alternations of seamed- and non-seamed 
bands; dissolution seams are abundant in the seamed band, which appears black while the nonseamed laminae appear white. The frequency of occurrence of dissolution seams decreases upward through a seamed band towards the gradational contact of the immediately overlying non-seamed band; bases of the non-seamed bands are, however, always sharp. The thin-bedded limestone facies is characterized by wave rippled bed tops. The calcarenite facies displays hummocky cross stratification (De Raaf et al 1977), climbing ripple laminae and unidirectional cross strata. The flakeconglomerate facies displays conspicuous edgewise fabric exhibited by flake-like carbonate intraclasts. Non-edgewise conglomerate facies displays chaotic arrangement of irregular clasts.

The presence of wave ripples, hummocky cross stratification and edgewise conglomerates in the Rohtas Limestone suggests deposition on the shelf. In the lower part, black shale alternates with dissolution seams bearing ribbon limestone facies, both lacking current features suggesting deep water sedimentation. Upward, the black shale facies is replaced by edgewise conglomerate facies, hummocky cross-stratified and wave rippled limestone indicating overall progradation. Lack of emergence features in these limestones suggests that the water level never became shallow. Ribbon limestone facies represents decoupling of beds into a lower compacted part and an upper uncompacted part; pre-compaction differential cementation has been inferred for the non-seamed bands (Banerjee et al 2005).

\subsection{Bhander Limestone}

Sarkar et al (1996) and Chakraborty (2004) have presented a detailed description of the facies and paleogeography of the Bhander Limestone. The ramp-originated Bhander Limestone succession is thought to have developed by forwardbackward shifts of shore-parallel facies belts between shoreface and distal offshore. The Bhander Limestone consists of five constituent facies whose depositional regime varied widely ranging from distal offshore to shoreface (table 3 , figure 6). Most of the facies are repetitive in nature and appear throughout the succession recording several transitions between offshore and nearshore domains. Amongst the constituent facies the stromatolite facies represents the widest range in paleogeography. Lateral transition of the stromatolite facies with the planar and cross-stratified ones has also been recorded. Sarkar et al (1998) and Chakraborty (2004) have recorded basin wide regression leading to exposure at three different levels marked by unconformities and correlative conformities.

\subsection{Mineralogical variation across the carbonate facies}

Out of the four carbonate units of the Vindhyan Supergroup the Fawn Dolostone is entirely dolomitic. Mineralogical data of the constituent facies of the remaining carbonate units are given in table 1 , table 2 and table 3 along with the description of facies. In the study area, the Rohtas Limestone consists predominantly of calcimicrites and calcisiltites (table 2). In Kajrahat Limestone small stromatolite facies, large stromatolite facies, microbial laminite facies and grey limestone facies consist solely of calcimicrites; whereas sheet bedded dolomite facies, cross-stratified dolomite and massive dolomite comprise predominantly of dolomicrites. In the case of Bhander Limestone the stromatolite facies and planar and cross-stratified facies are predominantly made up of calcite. Plane laminated limestone is, however, dolomitised frequently.

\section{Isotope compositions of the carbonate units}

\subsection{Primary carbon and oxygen isotope values for Paleoproterozoic to Neoproterozoic carbonates}

Many workers believe that C-isotopic signatures are usually well preserved in Proterozoic limestones (Knoll et al 1986). However, several examples of post-depositional isotopic shifts have been documented in recent years (Kaufmann et al 1992; Sarkar et al 1998; Ray et al 2003). Unfortunately, the $\delta^{13} \mathrm{C}$ and $\delta^{18} \mathrm{O}$ values of late Paleoproterozoic and Mesoproterozoic carbonates are not well constrained. Primary or near-original $\delta^{13} \mathrm{C}$ values for the late Paleoproterozoic to early Mesoproterozoic carbonates are found to be within $0 \pm 2 \%$ (Veizer et al 1992; Lindsay and Brasier 2000; Shields and Veizer 2002; Ray et al 2003). Near-original $\delta^{18} \mathrm{O}$ values of the calcitic carbonates for the entire Proterozoic is estimated to be $-6.5 \pm 1.5 \%$ (Ray et al 2003); contemporary dolomites are usually enriched in ${ }^{18} \mathrm{O}$ by $2-3 \%$ (Land 1980). The primary $\delta^{13} \mathrm{C}$ values of the Neoproterozoic carbonates are believed to be $3 \pm 2 \%$ (Ray et al 2003). In the following discussion the isotope ratios of the Vindhyan carbonate samples obtained by us have been compared with the primary range of values suggested by Ray et al (2003).

\subsection{Kajrahat Limestone}

$\delta^{13} \mathrm{C}$ values of 40 samples from different facies of the Kajrahat Limestone were measured and they 


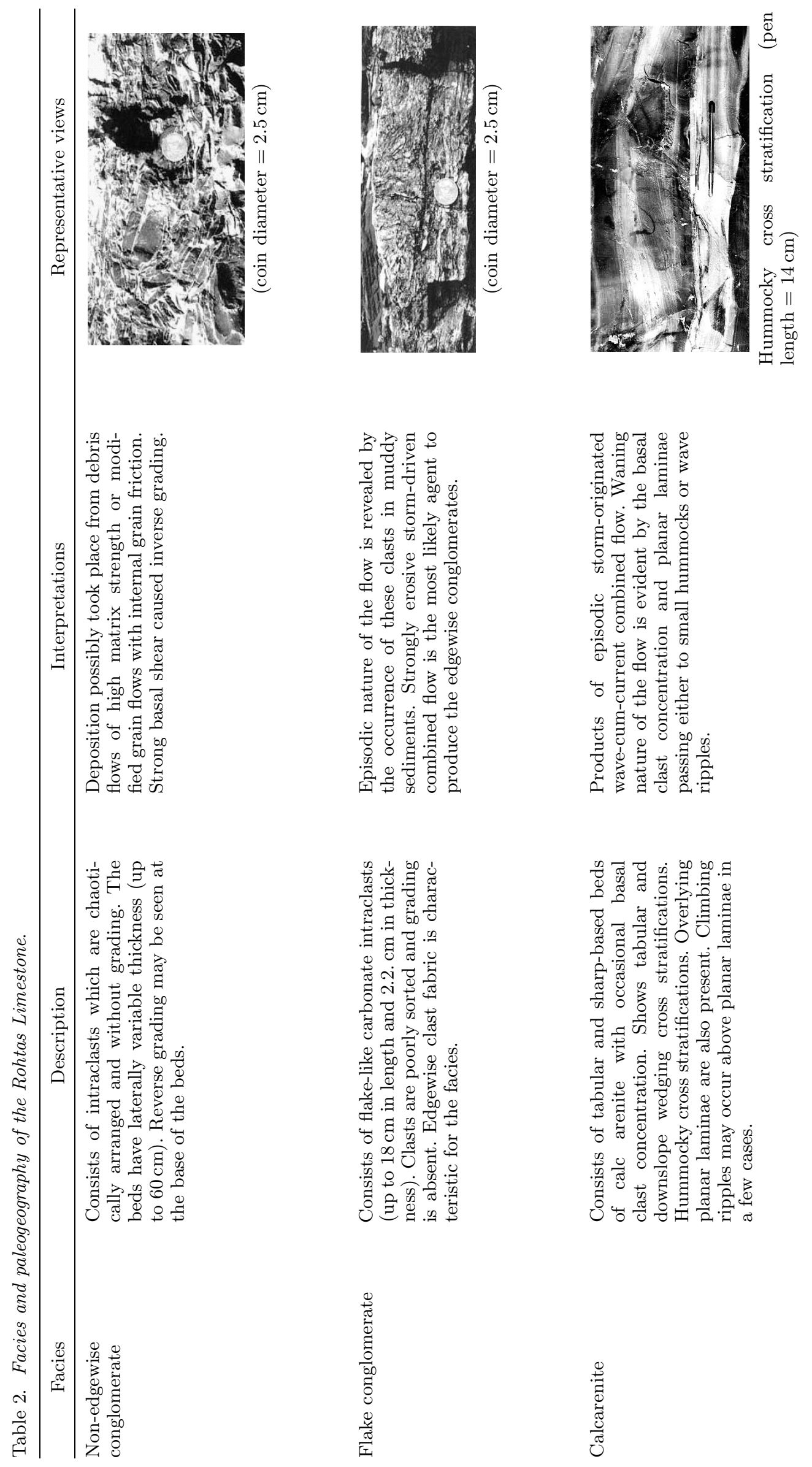



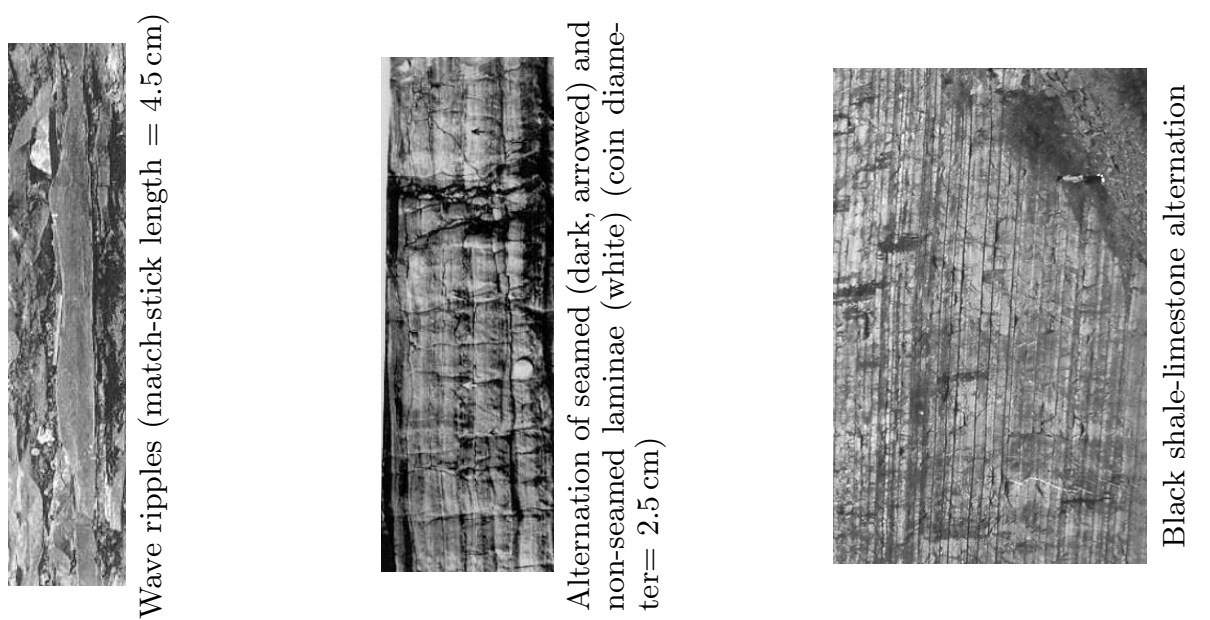

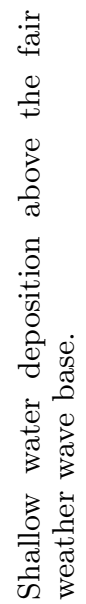
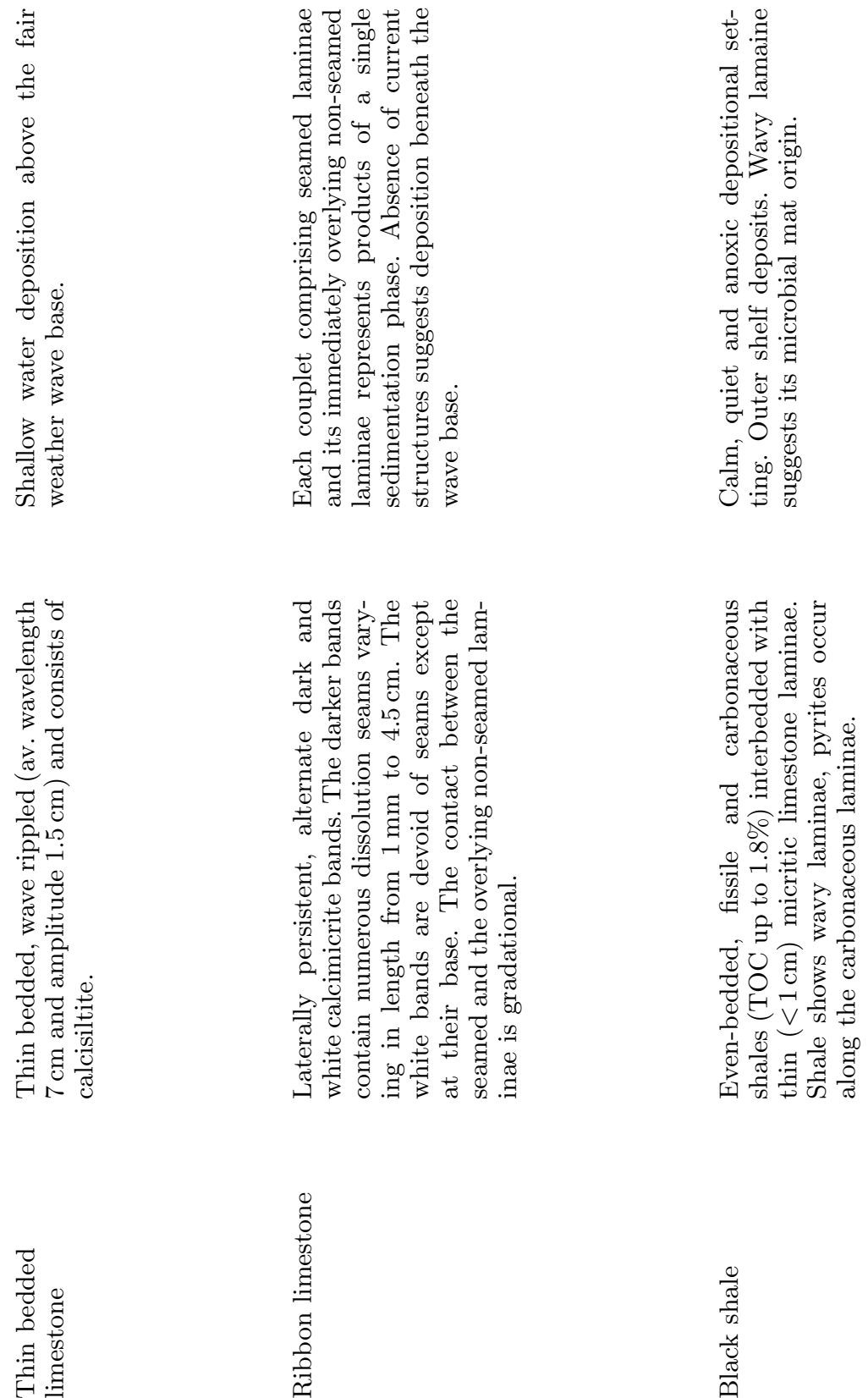

0
$\frac{0}{6}$
$\frac{\pi}{2}$
$\frac{0}{0}$
$\frac{\pi}{9}$ 


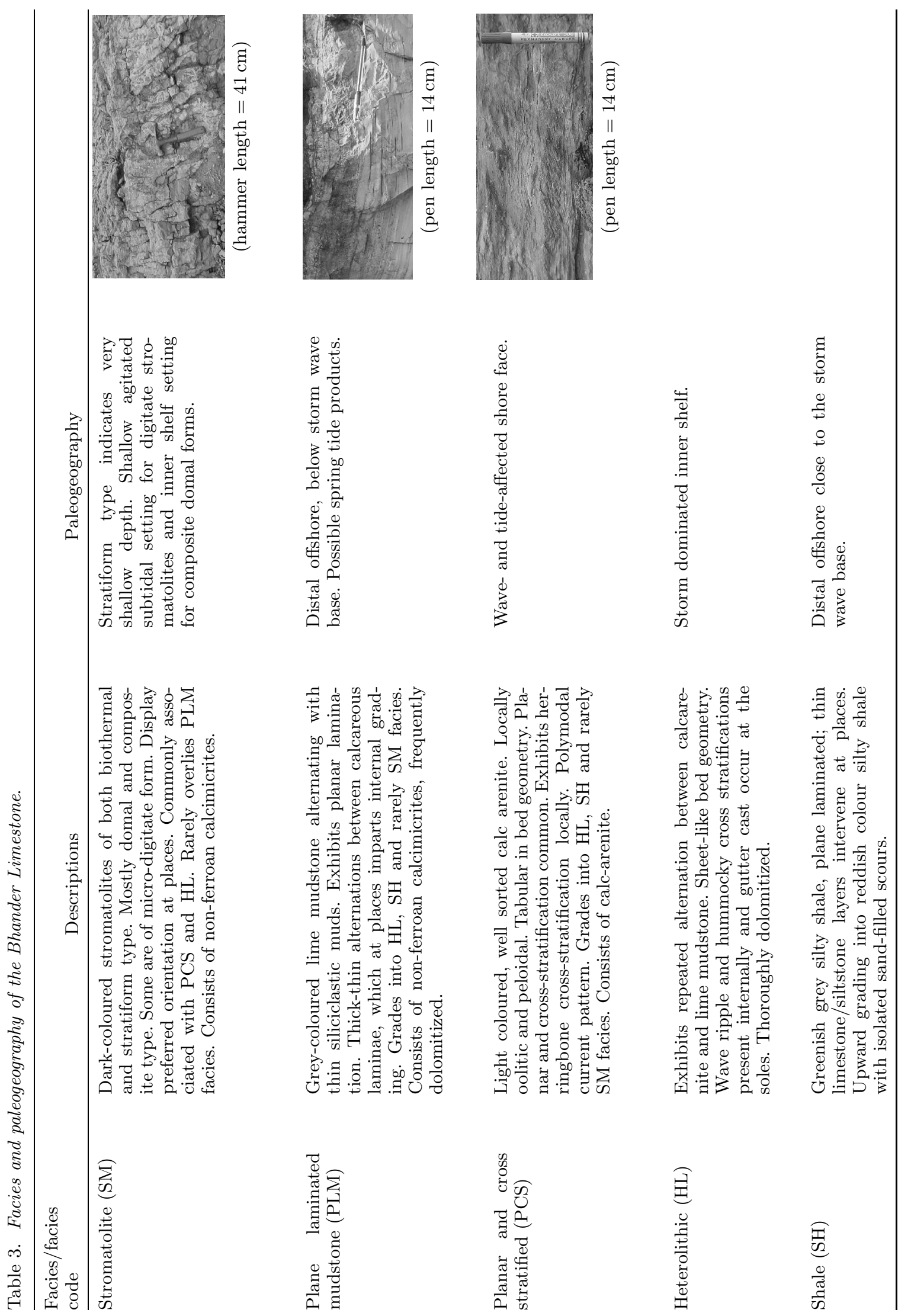




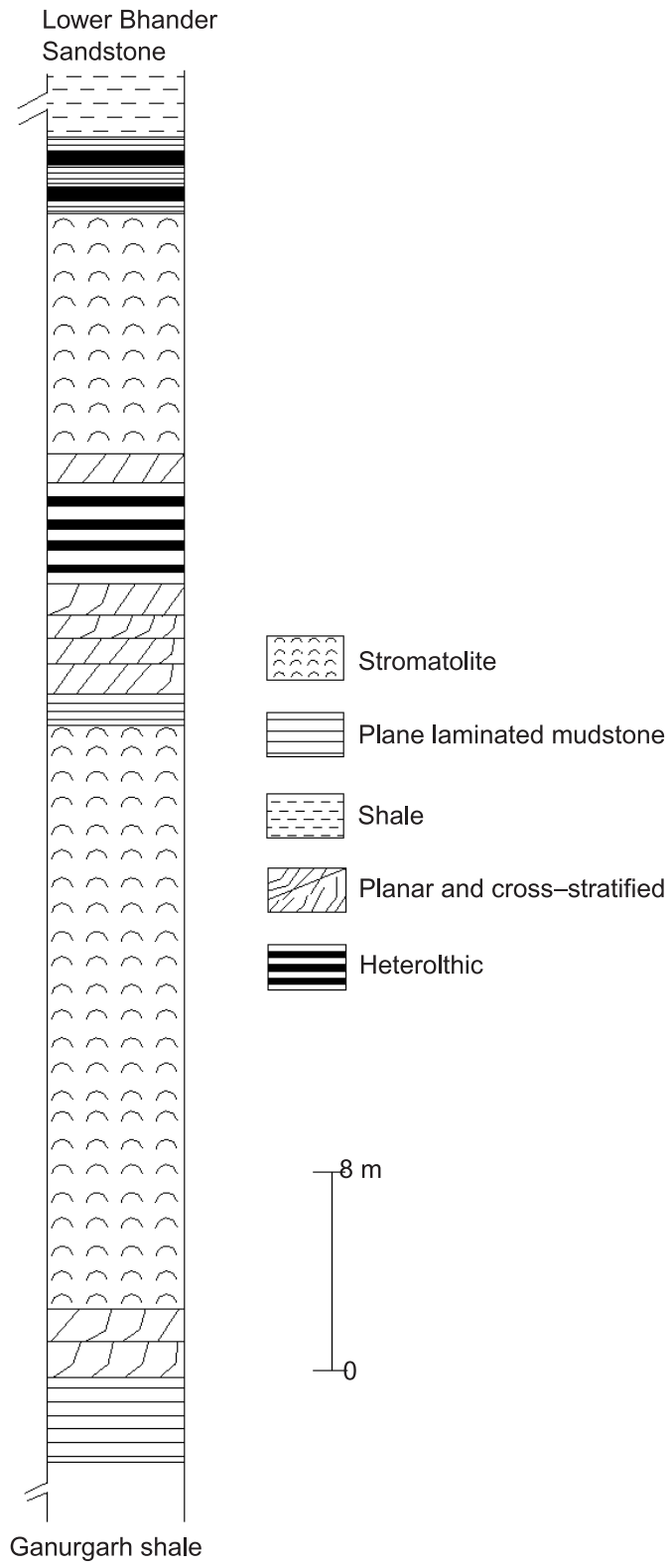

Figure 6. Representative log showing constituent facies of the Bhander Limestone in the Sajjanpur area.

range from $1.1 \%$ to $-2.5 \%$ (table 4 , figure $7 \mathrm{a}$ ). $\delta^{18} \mathrm{O}$ values for the same samples vary from $-7.9 \%$ to $-13.4 \%$ (figure $7 \mathrm{a}$ ). $\delta^{13} \mathrm{C}$ versus $\delta^{18} \mathrm{O}$ crossplot reveals conspicuous clusters of data points for individual facies. The sheet-bedded dolomite facies exhibits the highest $\delta^{13} \mathrm{C}$ and $\delta^{18} \mathrm{O}$ values while the microbial laminite facies exhibits the lowest ones. The average $\delta^{13} \mathrm{C}$ value shifts from low positive $(1.0 \%$ in sheet bedded dolomite facies and $0.3 \%$ in case of large stromatolite facies) to slightly negative $(-0.2 \%$ in massive dolomite facies and faintly laminated limestone facies, $-0.3 \%$ crossstratified dolomite facies and $-0.4 \%$ in small stromatolite facies) to still more negative $(-1.7 \%$ o in microbial laminite facies). A similar trend is also observed in the case of $\delta^{18} \mathrm{O}$ values; average $\delta^{18} \mathrm{O}$ value gradually shifts towards more negative values in the same hierarchy from sheet-bedded dolomite facies $(-9.3 \%$ in sheet-bedded dolomite facies, $-9.6 \%$ in larger stromatolite facies, $-10.3 \%$ in smaller stromatolite facies, $-10.6 \%$ in massive dolomite facies and microbial laminite facies, $-10.9 \%$ in faintly laminated limestone facies and $-11.7 \%$ in cross-stratified dolomite facies). Crossplot of $\delta^{13} \mathrm{C}$ and $\delta^{18} \mathrm{O}$ values shows moderate correlation with values from sheet-bedded dolomite facies and microbial laminite facies occupying two ends of the correlation line while values from other facies near the middle part of the correlation line (figure 7a). It also shows wide scatter of data points for the microbial laminite facies; amongst the microbially originated components of the upper division, the large stromatolite facies exhibits the least scatter and small stromatolite facies exhibits moderate scatter of data points. Amongst the seven carbonate facies sheet-bedded dolomite exhibits least scatter of data points and highest $\delta^{13} \mathrm{C}$ and $\delta^{18} \mathrm{O}$ values. In the upper division, each of the stromatolite cycles shows this general trend; $\delta^{13} \mathrm{C}$ and $\delta^{18} \mathrm{O}$ values become more depleted going across from large stromatolite facies to small stromatolite facies to microbial laminite facies. $\delta^{13} \mathrm{C}$ and $\delta^{18} \mathrm{O}$ values, thus, are unrelated to vertical stratigraphy and found to be dominantly faciescontrolled.

Moderate correlation of $\delta^{13} \mathrm{C}$ and $\delta^{18} \mathrm{O}$ values $\left(\mathrm{r}^{2}=0.3\right)$ and wide scatter of the data points of the Kajrahat Limestone possibly suggest alteration of most carbon and oxygen isotope values. Except the microbial laminite facies the $\delta^{13} \mathrm{C}$ values of the remaining facies remain confined within a narrow range (close to $0 \%$ ).$\delta^{18} \mathrm{O}$ values of the samples exhibit wide variation. It can be surmised that the alteration effect is less pronounced in the case of carbon isotopes. It seems that the higher $\delta$-values, e.g., those for the sheet-bedded dolomite facies and the large stromatolite facies are least altered and represent near-primary ratios (Veizer et al 1992). Higher $\delta^{18} \mathrm{O}$ values in sheet bedded dolomite facies may also be related to dolomitic mineralogy of the samples (Land 1980). As mentioned before, most of the facies constituting the Kajrahat Limestone bears evidence of exposure of the depositional substrate. The $\delta^{13} \mathrm{C}$ and $\delta^{18} \mathrm{O}$ values of small stromatolites and microbial laminites and even cross-stratified dolomites and sheet bedded dolomites probably represent alteration by isotopically lighter fluids at an early stage of diagenesis. Such isotopically lighter fluids can be generated either by organic maturation during burial or organically charged meteoric water (see also Booler and Tucker 2002). Lack of compaction within the Kajrahat Limestone, however, suggests 
Table 4. Carbon and oxygen isotope compositions for the constituent facies of the Kajrahat Limestone.

\begin{tabular}{|c|c|c|c|c|}
\hline Sample no. & Facies & $\begin{array}{l}\text { Distance from the } \\
\text { base of the member }\end{array}$ & $\delta^{13} \mathrm{C}(\% 0)$ & $\delta^{18} \mathrm{O}(\% 0)$ \\
\hline $\mathrm{KJ}-40$ & Microbial laminite & $250.4 \mathrm{~m}$ & -0.5 & -12.5 \\
\hline KJ-39 & Microbial laminite & $248.3 \mathrm{~m}$ & -2.2 & -9.2 \\
\hline KJ-38 & Microbial laminite & $247.4 \mathrm{~m}$ & -1.5 & -11.7 \\
\hline KJ-37 & Microbial laminite & $234.3 \mathrm{~m}$ & -1.9 & -9.8 \\
\hline KJ-36 & Microbial laminite & $233.4 \mathrm{~m}$ & -2.2 & -7.9 \\
\hline KJ-35 & Microbial laminite & $232.3 \mathrm{~m}$ & -0.3 & -10.0 \\
\hline KJ-34 & Microbial laminite & $192.4 \mathrm{~m}$ & -1.3 & -12.8 \\
\hline KJ-33 & Microbial laminite & $191.4 \mathrm{~m}$ & -1.7 & -10.6 \\
\hline KJ-32 & Microbial laminite & $190.3 \mathrm{~m}$ & -2.5 & -12.5 \\
\hline KJ-31 & Small stromatolite & $250.4 \mathrm{~m}$ & -0.9 & -9.7 \\
\hline KJ-30 & Small stromatolite & $248.2 \mathrm{~m}$ & -0.7 & -11.0 \\
\hline KJ-29 & Small stromatolite & $247.1 \mathrm{~m}$ & -0.2 & -9.8 \\
\hline $\mathrm{KJ}-28$ & Small stromatolite & $234.2 \mathrm{~m}$ & -0.3 & -9.2 \\
\hline KJ-27 & Small stromatolite & $233.2 \mathrm{~m}$ & -0.4 & -10.8 \\
\hline KJ-26 & Small stromatolite & $232.1 \mathrm{~m}$ & -0.4 & -10.0 \\
\hline KJ-25 & Small stromatolite & $192.2 \mathrm{~m}$ & -0.2 & -10.3 \\
\hline $\mathrm{KJ}-24$ & Small stromatolite & $191.1 \mathrm{~m}$ & -0.3 & -11.5 \\
\hline KJ-23 & Small stromatolite & $190.2 \mathrm{~m}$ & -0.5 & -10.4 \\
\hline KJ-22 & Large stromatolite & $250 \mathrm{~m}$ & 0.3 & -9.6 \\
\hline KJ-21 & Large stromatolite & $248 \mathrm{~m}$ & 0.2 & -9.2 \\
\hline KJ-20 & Large stromatolite & $247 \mathrm{~m}$ & 0.1 & -10.1 \\
\hline KJ-19 & Large stromatolite & $234 \mathrm{~m}$ & 0.9 & -9.7 \\
\hline KJ-18 & Large stromatolite & $233 \mathrm{~m}$ & 0.5 & -9.6 \\
\hline KJ-17 & Large stromatolite & $232 \mathrm{~m}$ & 0.2 & -8.4 \\
\hline KJ-16 & Large stromatolite & $192 \mathrm{~m}$ & 0.2 & -9.2 \\
\hline KJ-15 & Large stromatolite & $191 \mathrm{~m}$ & 0.4 & -10.7 \\
\hline KJ-14 & Large stromatolite & $190 \mathrm{~m}$ & 0.1 & -10.0 \\
\hline KJ-13 & Sheet bedded dolomite & $129 \mathrm{~m}$ & 1.0 & -9.0 \\
\hline KJ-12 & Sheet bedded dolomite & $115.1 \mathrm{~m}$ & 0.9 & -9.7 \\
\hline KJ-11 & Sheet bedded dolomite & $103.1 \mathrm{~m}$ & 1.0 & -9.4 \\
\hline KJ-10 & Sheet bedded dolomite & $72.1 \mathrm{~m}$ & 1.0 & -9.2 \\
\hline KJ-9 & Sheet bedded dolomite & $61.1 \mathrm{~m}$ & 1.1 & -9.3 \\
\hline $\mathrm{KJ}-8$ & Grey limestone & $115 \mathrm{~m}$ & -0.1 & -10.9 \\
\hline KJ-7 & Grey limestone & $103 \mathrm{~m}$ & -0.1 & -11.0 \\
\hline KJ-6 & Grey limestone & $72 \mathrm{~m}$ & -0.1 & -11.1 \\
\hline KJ-5 & Grey limestone & $61 \mathrm{~m}$ & -0.3 & -10.8 \\
\hline $\mathrm{KJ}-4$ & Cross stratified dolomite & $48 \mathrm{~m}$ & -0.2 & -13.4 \\
\hline KJ-3 & Cross stratified dolomite & $45 \mathrm{~m}$ & -0.3 & -11.3 \\
\hline KJ-2 & Cross stratified dolomite & $28 \mathrm{~m}$ & -0.5 & -10.4 \\
\hline KJ-1 & Massive dolomite & $24 \mathrm{~m}$ & -0.2 & -10.6 \\
\hline
\end{tabular}

that diagenetic resetting of carbon and oxygen isotope compositions took place in near surface conditions. Amongst the microbially originated facies of the upper division, microbial laminite facies, as well as both large and small stromatolites, show emergence features. However, the isotope ratios of large stromatolites are least altered. Scatter in data points and moderate correlation of values in the case of larger stromatolites suggest minor alteration from original values indicating a 


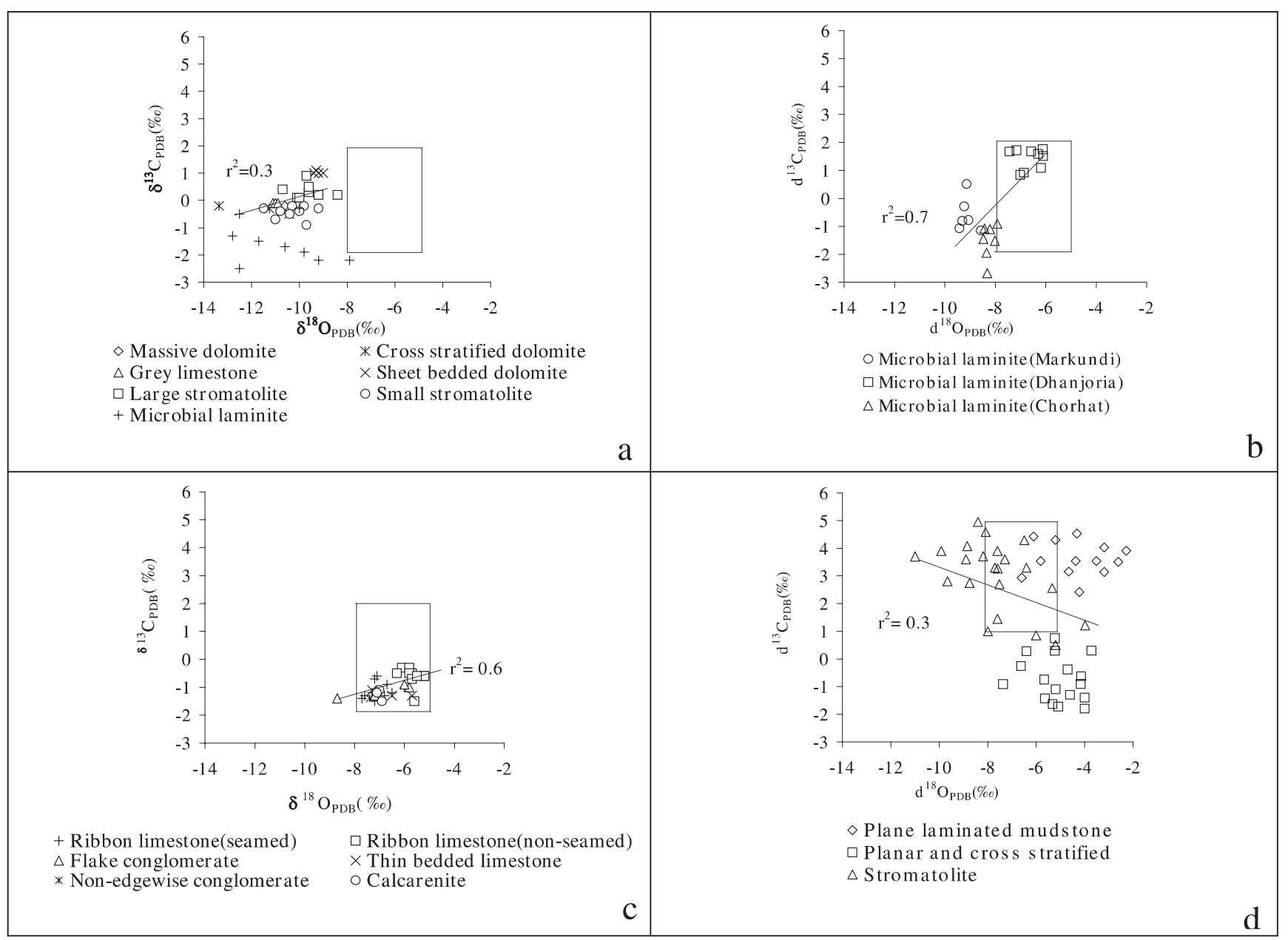

Figure 7. $\quad \delta^{13} \mathrm{C}$ versus $\delta^{18} \mathrm{O}$ plot of the samples of the constituent facies of the Kajrahat Limestone samples displaying wide scatter of data points (a). $\delta^{13} \mathrm{C}$ versus $\delta^{18} \mathrm{O}$ plot of the Fawn Dolomite samples from three areas, namely Chorhat, Markundi and Dhanjoria (b). $\delta^{13} \mathrm{C}$ versus $\delta^{18} \mathrm{O}$ plot of the samples of the constituent facies of the Rohtas Limestone samples (c) and Bhander Limestone (d). Primary box of Ray et al (2003) is indicated by the rectangle in each figure. Note that none of the samples of the Kajrahat Limestone plot within the primary box and all but one sample of the Rohtas Limestone plots outside the primary box.

short duration of exposure in this case (Joachimsky 1994). Microbial laminites, on the contrary, show large depletion of $\delta^{13} \mathrm{C}$ and $\delta^{18} \mathrm{O}$ values suggesting longer duration of exposure. Small stromatolites show moderate depletion of $\delta^{13} \mathrm{C}$ and $\delta^{18} \mathrm{O}$ values in comparison to the large stromatolites. It is possible that the composition of the meteoric fluids varied over time causing the observed scatter in the $\delta$-values. Similar fluctuations in response to shallowing leading to exposure have been documented from many Phanerozoic sequences (Joachimsky 1994). $\delta^{18} \mathrm{O}$ values of the Kajrahat Limestone are highly depleted compared to contemporaneous carbonates and possibly represent considerable diagenetic alteration. As a consequence, none of the values plot within the primary box of Ray et al (2003) although the range of $\delta^{13} \mathrm{C}$ values remains within the 'primary' range (figure $7 \mathrm{a}$ ). Diagenetic fluids do not contain much $\mathrm{CO}_{2}$ to reset original carbon isotope signature unless the alteration effect is extensive and the original carbonate sediments are thoroughly recrystallised. Significant post depositional resetting leading to lowering of $\delta^{18} \mathrm{O}$ values took place possibly for most of the samples of the Kajrahat Limestone.

\subsection{Fawn Dolomite}

Stable isotope compositions of time equivalent dolomite bodies of the Kheinjua Formation (Fawn Dolomite) vary considerably (table 5 ). The data points of Chorhat, Markundi and Dhanjoria samples form three separate clusters (figure $7 \mathrm{~b}$ ). The data points of the Fawn Dolostone exhibit good correlation between $\delta^{13} \mathrm{C}$ and $\delta^{18} \mathrm{O}$ values $\left(\mathrm{r}^{2}=0.7\right)$. The Chorhat samples are characterized by consistently negative $\delta^{13} \mathrm{C}$ values ranging from $-0.9 \%$ to $-2.8 \%$ with an average of $-1.9 \%$. In contrast, the Dhanjoria samples exhibit consistently positive $\delta^{13} \mathrm{C}$ values ranging from $0.9 \%$ to 
Table 5. Carbon and oxygen isotope compositions of the Fawn Dolostone in different places.

\begin{tabular}{|c|c|c|c|}
\hline Sample no. & Facies/ lithology & $\delta^{13} \mathrm{C}(\% 0)$ & $\delta^{18} \mathrm{O}(\% 0)$ \\
\hline \multicolumn{4}{|c|}{ Chorhat section } \\
\hline Kh-11 & Microbial laminite & -1.1 & -8.2 \\
\hline Kh-10 & Microbial laminite & -1.5 & -8.0 \\
\hline Kh-9 & Microbial laminite & -0.9 & -7.9 \\
\hline Kh-8 & Microbial laminite & -1.5 & -8.5 \\
\hline Kh-7 & Microbial laminite & -1.1 & -8.4 \\
\hline Kh-6 & Microbial laminite & -1.9 & -8.4 \\
\hline Kh-5 & Microbial laminite & -2.7 & -8.3 \\
\hline Kh-4 & Microbial laminite & -2.4 & -8.5 \\
\hline Kh-3 & Microbial laminite & -2.5 & -8.2 \\
\hline Kh-2 & Microbial laminite & -2.2 & -7.9 \\
\hline Kh-1 & Microbial laminite & -2.8 & -8.1 \\
\hline \multicolumn{4}{|c|}{ Dhanjoria section } \\
\hline Kh-20 & Microbial laminite & 1.5 & -6.1 \\
\hline Kh-19 & Microbial laminite & 1.6 & -7.4 \\
\hline Kh-18 & Microbial laminite & 1.7 & -7.2 \\
\hline Kh-17 & Microbial laminite & 1.6 & -6.3 \\
\hline Kh-16 & Microbial laminite & 1.7 & -6.6 \\
\hline Kh-15 & Microbial laminite & 1.8 & -6.1 \\
\hline Kh-14 & Microbial laminite & 1.1 & -6.2 \\
\hline Kh-13 & Microbial laminite & 0.9 & -7.0 \\
\hline Kh-12 & Microbial laminite & 0.9 & -6.8 \\
\hline \multicolumn{4}{|c|}{ Markundi section } \\
\hline Kh-26 & Microbial laminite & -0.8 & -9.3 \\
\hline $\mathrm{Kh}-25$ & Microbial laminite & -0.3 & -9.2 \\
\hline Kh-24 & Microbial laminite & -1.1 & -9.4 \\
\hline $\mathrm{Kh}-23$ & Microbial laminite & -0.8 & -9.1 \\
\hline Kh-22 & Microbial laminite & 0.5 & -9.1 \\
\hline Kh-21 & Microbial laminite & -1.2 & -8.6 \\
\hline
\end{tabular}

$1.8 \%$ the average being $1.4 \%$. The Markundi samples exhibit $\delta^{13} \mathrm{C}$ values ranging between $0.5 \%$ to $-1.2 \%$ and are highly depleted in $\delta^{18} \mathrm{O} . \delta^{18} \mathrm{O}$ values of the samples steadily become more negative from Dhanjoria (average $-6.6 \%$ ) to Chorhat (average $-8.2 \%$ ) to Markundi (average $-9.1 \%$ ).

The formation of distinct clusters of data points for samples collected from different localities suggests dominant control of paleogeography and local pore fluid on the isotope compositions. As all the samples are mainly dolomitic clustering of points in separate groups it cannot be attributed to mineralogical variation. Diagenetic alteration by meteoric water is equivocal in the inferred depositional setting for the Fawn Dolomite. Meteoric fluids of different compositions might have shifted original carbon and oxygen isotope values towards depleted values. $\delta^{13} \mathrm{C}$ and $\delta^{18} \mathrm{O}$ values of most of the Dhanjoria samples remain restricted within a narrow range and possibly represent the original carbon and oxygen isotope signature. However, $\delta^{18} \mathrm{O}$ values of the Markundi samples are much depleted and $\delta^{13} \mathrm{C}$ values of the same exhibit a wider range. Modest alteration by isotopically lighter fluids is suggested in the latter case. Good correlation between $\delta^{13} \mathrm{C}$ and $\delta^{18} \mathrm{O}$ values further suggests possible meteoric diagenetic alteration of the dolomites whose original composition was very much similar to the Dhanjoria samples. Petrographic studies show several generations of pore-filling cements within the peloidal dolomites (figures 4c, 4d), corroborating pervasive diagenetic alteration. Ray et al (2003) recorded very high $\mathrm{Mn} / \mathrm{Sr}$ and ${ }^{87} \mathrm{Sr} /{ }^{86} \mathrm{Sr}$ and considered that the samples belonging to the Fawn Dolomite are heavily altered. Paleogeographic setting of the Fawn 
Table 6. Carbon and oxygen isotope composition for the constituent facies of the Rohtas Limestone.

\begin{tabular}{|c|c|c|c|c|}
\hline $\begin{array}{c}\text { Sample } \\
\text { no. }\end{array}$ & Facies & $\begin{array}{l}\text { Distance from } \\
\text { the base of } \\
\text { the member }\end{array}$ & $\delta^{13} \mathrm{C}(\%)$ & $\delta^{18} \mathrm{O}(\%)$ \\
\hline RL-31 & Thin bedded limestone & 152 & -1.3 & -5.7 \\
\hline RL-30 & Flake conglomerate, clasts & 151 & -1.4 & -8.7 \\
\hline RL-29 & Calcarenite & 149 & -1.5 & -6.9 \\
\hline RL-28 & Calcarenite & 147 & -1.1 & -7.0 \\
\hline RL-27 & Calcarenite & 143 & -1.2 & -7.1 \\
\hline RL-26 & Flake conglomerates, clasts & 140 & -1.3 & -7.2 \\
\hline RL-25 & Non-edgewise conglomerate, clasts & 90 & -1.4 & -7.4 \\
\hline RL-24 & Thin bedded limestone & 85 & -1.3 & -6.5 \\
\hline RL-23 & Thin bedded limestone & 72 & -1.1 & -7.3 \\
\hline RL-22 & Flake conglomerates, clasts & 15.5 & -1.0 & -5.8 \\
\hline RL-21 & Flake conglomerates, clasts & 5.6 & -0.9 & -6.0 \\
\hline RL-20 & Ribbon limestone, non-seamed & 23 & -0.6 & -5.2 \\
\hline RL-19 & Ribbon limestone, seamed & 23 & -1.3 & -6.8 \\
\hline RL-18 & Ribbon limestone, non-seamed & 21 & -0.6 & -5.2 \\
\hline RL-17 & Ribbon limestone, seamed & 21 & -1.0 & -6.0 \\
\hline RL-16 & Ribbon limestone, non-seamed & 20 & -0.5 & -5.7 \\
\hline RL-15 & Ribbon limestone, seamed & 20 & -1.2 & -6.5 \\
\hline RL-14 & Ribbon limestone, non-seamed & 18 & -0.3 & -6.1 \\
\hline RL-13 & Ribbon limestone, seamed & 18 & -0.7 & -7.2 \\
\hline RL-12 & Ribbon limestone, non-seamed & 15 & -0.3 & -5.8 \\
\hline RL-11 & Ribbon limestone, seamed & 15 & -0.6 & -7.1 \\
\hline RL-10 & Ribbon limestone, non-seamed & 12 & -0.5 & -5.8 \\
\hline RL-9 & Ribbon limestone, seamed & 12 & -0.9 & -6.7 \\
\hline RL-8 & Ribbon limestone, non-seamed & 8.5 & -1.5 & -5.6 \\
\hline RL-7 & Ribbon limestone, seamed & 8.5 & -1.3 & -7.6 \\
\hline RL-6 & Ribbon limestone, non-seamed & 6 & -0.7 & -5.7 \\
\hline RL-5 & Ribbon limestone, seamed & 6 & -1.5 & -7.2 \\
\hline RL-4 & Ribbon limestone, non-seamed & 3.5 & -0.5 & -6.3 \\
\hline RL-3 & Ribbon limestone, seamed & 3.5 & -1.4 & -7.7 \\
\hline RL-2 & Ribbon limestone, non-seamed & 2 & -0.6 & -5.5 \\
\hline RL-1 & Ribbon limestone, seamed & 2 & -1.2 & -7.3 \\
\hline
\end{tabular}

Dolomite is the main cause of such an extensive alteration of primary isotope values. As a consequence of such extensive alteration possibly most of the samples of Markundi and Chorhat plot outside the primary box of Ray et al (2003); only the samples of Dhanjoria plot inside the primary box.

\subsection{Rohtas Limestone}

Isotope analyses of 31 samples from all the facies constituting the Rohtas Limestone are given in table 6 and shown in figure 7 (c). 20 samples belong to the 10 couplets of the seamed-and non-seamed bands. $\delta{ }^{13} \mathrm{C}$ values of the samples remain restricted in a narrow range from $-1.5 \%$ to $-0.3 \%$ (average
$-1 \%$ ) whereas $\delta^{18} \mathrm{O}$ values range from $-5.2 \%$ to $-8.7 \%$ (average $-6.5 \%$ ). $\delta^{13} \mathrm{C}$ versus $\delta^{18} \mathrm{O}$ crossplot reveals two broad clusters of data points, one dominated by ribbon limestone facies (seamed part) and the other consists of data points belonging mostly to ribbon limestone facies (but being the non-seamed part). There is a modest correlation between $\delta^{13} \mathrm{C}$ and $\delta^{18} \mathrm{O}$ values $\left(\mathrm{r}^{2}=0.6\right)$. Samples of the calc-arenite facies and thin-bedded limestone facies also plot in the latter cluster. $\delta^{13} \mathrm{C}$ and $\delta^{18} \mathrm{O}$ ratios of 10 couplets taken from the seamed and non-seamed bands in ribbon limestone facies reveal a systematic pattern of variation. Every upward transition from seamed lamina to its overlying non-seamed lamina is associated with enrichment in heavy carbon and oxygen isotopes. Within 
Table 7. Carbon and oxygen isotope composition of the constituent facies of the Bhander Limestone.

\begin{tabular}{|c|c|c|c|}
\hline Sample no. & Facies & $\delta^{13} \mathrm{C}(\% 0)$ & $\delta^{18} \mathrm{O}(\%)$ \\
\hline \multicolumn{4}{|c|}{ Maihar section } \\
\hline 1/PLM & Plane laminated mudstone & -6.6 & 2.9 \\
\hline 2/PLM & Plane laminated mudstone & -3.5 & 3.5 \\
\hline 3/PLM & Plane laminated mudstone & -6.1 & 4.4 \\
\hline 4/PLM & Plane laminated mudstone & -4.4 & 3.5 \\
\hline 5/PLM & Plane laminated mudstone & -2.6 & 3.5 \\
\hline 6/PLM & Plane laminated mudstone & -3.2 & 4.0 \\
\hline 7/PLM & Plane laminated mudstone & -4.2 & 2.4 \\
\hline \multicolumn{4}{|c|}{ Satna section } \\
\hline 8/PLM & Plane laminated mudstone & -5.2 & 4.3 \\
\hline 9/PLM & Plane laminated mudstone & -5.8 & 3.5 \\
\hline 10/PLM & Plane laminated mudstone & -4.3 & 4.5 \\
\hline 11/PLM & Plane laminated mudstone & -3.2 & 3.1 \\
\hline 12/PLM & Plane laminated mudstone & -4.7 & 3.2 \\
\hline 13/PLM & Plane laminated mudstone & -2.3 & 3.9 \\
\hline \multicolumn{4}{|c|}{ Maihar section } \\
\hline 1/PCS & Planar and cross-stratified & -5.1 & -1.7 \\
\hline 2/PCS & Planar and cross-stratified & -5.3 & -1.6 \\
\hline 3/PCS & Planar and cross-stratified & -7.4 & -0.9 \\
\hline 4/PCS & Planar and cross-stratified & -4.1 & -0.6 \\
\hline $5 / \mathrm{PCS}$ & Planar and cross-stratified & -5.6 & -1.4 \\
\hline $6 / \mathrm{PCS}$ & Planar and cross-stratified & -5.2 & 0.3 \\
\hline $7 / \mathrm{PCS}$ & Planar and cross-stratified & -5.2 & 0.8 \\
\hline \multicolumn{4}{|c|}{ Satna section } \\
\hline 8/PCS & Planar and cross-stratified & -4.7 & -0.4 \\
\hline 9/PCS & Planar and cross-stratified & -3.7 & 0.3 \\
\hline 10/PCS & Planar and cross-stratified & -5.7 & -0.8 \\
\hline $11 / \mathrm{PCS}$ & Planar and cross-stratified & -4.2 & -0.9 \\
\hline $12 / \mathrm{PCS}$ & Planar and cross-stratified & -6.4 & 0.3 \\
\hline $13 / \mathrm{PCS}$ & Planar and cross-stratified & -6.6 & -0.3 \\
\hline $14 / \mathrm{PCS}$ & Planar and cross-stratified & -5.2 & -1.1 \\
\hline \multicolumn{4}{|c|}{ Aber section } \\
\hline $15 / \mathrm{PCS}$ & Planar and cross-stratified & -4.6 & -1.3 \\
\hline $16 / \mathrm{PCS}$ & Planar and cross-stratified & -4 & -1.8 \\
\hline $17 / \mathrm{PCS}$ & Planar and cross-stratified & -4 & -1.4 \\
\hline \multicolumn{4}{|c|}{ Maihar section } \\
\hline $1 / \mathrm{SM}$ & Stromatolite & -5.2 & 0.5 \\
\hline $2 / \mathrm{SM}$ & Stromatolite & -7.6 & 1.5 \\
\hline $3 / \mathrm{SM}$ & Stromatolite & -6.5 & 4.3 \\
\hline 4/SM & Stromatolite & -8.1 & 4.6 \\
\hline $5 / \mathrm{SM}$ & Stromatolite & -9.9 & 3.9 \\
\hline $6 / \mathrm{SM}$ & Stromatolite & -8.9 & 4.1 \\
\hline $7 / \mathrm{SM}$ & Stromatolite & -8.2 & 3.7 \\
\hline 8/SM & Stromatolite & -7.6 & 3.3 \\
\hline
\end{tabular}


Table 7. (Continued).

\begin{tabular}{lccc}
\hline Sample no. & Facies & $\delta^{13} \mathrm{C}(\%)$ & $\delta^{18} \mathrm{O}(\%)$ \\
\hline Sajjanpur section & & & \\
9/SM & Stromatolite & -9.7 & 2.8 \\
$10 / \mathrm{SM}$ & Stromatolite & -5.3 & 2.6 \\
$11 / \mathrm{SM}$ & Stromatolite & -3.9 & 1.2 \\
\hline Aber section & & & \\
$12 / \mathrm{SM}$ & Stromatolite & -6.4 & 3.3 \\
$13 / \mathrm{SM}$ & Stromatolite & -11 & 3.7 \\
$14 / \mathrm{SM}$ & Stromatolite & -8 & 1 \\
$15 / \mathrm{SM}$ & Stromatolite & -7.6 & 3.9 \\
$16 / \mathrm{SM}$ & Stromatolite & -7.7 & 3.3 \\
$17 / \mathrm{SM}$ & Stromatolite & -8.9 & 3.6 \\
$18 / \mathrm{SM}$ & Stromatolite & -7.3 & 3.6 \\
$19 / \mathrm{SM}$ & Stromatolite & -7.5 & 2.7 \\
$20 / \mathrm{SM}$ & Stromatolite & -8.8 & 2.8 \\
$21 / \mathrm{SM}$ & Stromatolite & -6 & 0.9 \\
$22 / \mathrm{SM}$ & Stromatolite & -8.4 & 4.9 \\
\hline
\end{tabular}

each couplet, the non-seamed band is enriched in ${ }^{18} \mathrm{O}$ by $0.7 \%$ to $2.1 \%$ (average $1.2 \%$ ). The same trend is also recorded in ${ }^{13} \mathrm{C}$ (non-seamed band is enriched in ${ }^{13} \mathrm{C}$, average enrichment being $0.6 \%$ ). The shifts are minor in magnitude but significant in their recurrent unidirectional nature and high frequency.

The depositional setting for the Rohtas Limestone was confined to shelf zones. None of the constituent facies represent emergence of the depositional substrate above water level ruling out diagenetic resetting of isotope compositions by meteoric water. The data points of the Rohtas Limestone are, therefore, most likely to retain the original isotope composition. The tight cluster of the data points and the narrow range of $\delta^{13} \mathrm{C}$ values from $-1.5 \%$ to $-0.3 \%$ suggest possible retention of primary isotope signature in most of the samples of Rohtas Limestone. Differential cementation, however, caused marginal shifts in $\delta^{13} \mathrm{C}$ and $\delta^{18} \mathrm{O}$ values within the alternate bands of ribbon limestone facies (Banerjee et al 2005). The non-seamed laminae in ribbon limestone facies are always enriched in heavier isotopes of carbon and oxygen than the seamed laminae. The modest correlation between $\delta^{13} \mathrm{C}$ and $\delta^{18} \mathrm{O}$ values can be explained by genetically linked $\delta^{13} \mathrm{C}$ and $\delta^{18} \mathrm{O}$ variations of the seamed- and non-seamed laminae. Banerjee et al (2005) attributed such repeated shifts in the ribbon limestone facies to pre-compaction differential cementation of the non-seamed bands. Marine cements are always isotopically heavier than the marine sediments; abundance of such cements within the non-seamed bands can account for the observed enrichment of heavier isotopes in the non-seamed bands (Banerjee et al 2005). Most of the data points of the Rohtas Limestones plot within the primary box of Ray et al (2003) and thereby corroborate the fact that neither $\delta^{13} \mathrm{C}$ nor $\delta^{18} \mathrm{O}$ values are affected by meteoric diagenesis.

\subsection{Bhander Limestone}

In a cross-plot of $\delta^{13} \mathrm{C}$ versus $\delta^{18} \mathrm{O}$ the data points belonging to the three constituent facies of Bhander Limestone, e.g., plane laminated mudstone, stromatolites and planar and cross-stratified limestone plot as three separate clusters with very little overlap (table 7, figure 7d). Overall the data points of the Bhander Limestone exhibit a wide scatter (compare figure 7a-d). Figure 10 shows weak negative correlation between $\delta^{13} \mathrm{C}$ and $\delta^{18} \mathrm{O}$ values $\left(r^{2}=0.3\right)$. The data points of the stromatolite facies exhibit larger scatter in comparison to those belonging to the planar and cross-stratified facies and plane laminated mudstone facies. The samples from the stromatolite facies exhibit consistently positive $\delta^{13} \mathrm{C}$ values ranging from $0.5 \%$ to $4.9 \%$ (average 3\%o). The samples of plane laminated mudstone facies also display consistently positive $\delta^{13} \mathrm{C}$ values ranging between $2.9 \%$ and $4.5 \%$ (average $3.6 \%$ ), whereas the planar and cross-stratified limestone exhibit low negative to low positive values ranging between $-1.8 \%$ and $0.3 \%$. Average $\delta^{18} \mathrm{O}$ values for stromatolite facies and for plane laminated mudstone facies are $-7.7 \%$ and 
$-4.3 \%$, respectively. Planar and cross-stratified facies exhibit intermediate $\delta^{18} \mathrm{O}$ values ranging between $-4 \%$ and $-7.4 \%$ (average $-5.1 \%$ ).

The occurrence of separate clusters of data points belonging to different facies suggests that the carbon and oxygen isotope compositions are to a large extent controlled by the nature of the facies. Amongst all the carbonate units of the Vindhyan Supergroup the data points of the Bhander Limestone represent a wide scatter (compare figure $7 \mathrm{a}$ to d) and correlation between $\delta^{13} \mathrm{C}$ and $\delta^{18} \mathrm{O}$ values of the samples is very poor. Moderate alteration of isotope compositions is thereby suggested for most of the samples of the Bhander Limestone. Depositional regime for the Bhander Limestone varied widely extending from distal offshore to shoreface, the planar and cross-stratified facies representing the shallowest bathymetry. Therefore, the observed depletion of $\delta^{13} \mathrm{C}$ in planar and crossstratified limestone is possibly because of extensive diagenetic alteration due to prolonged exposure in sub-aerial condition. Sarkar et al (1998) reported extremely depleted $\delta^{13} \mathrm{C}$ values in meteoric diagenetic cements close to the unconformity surfaces where the $\delta^{18} \mathrm{O}$ values of the same cements were similar to that of the carbonate sediments. It is intriguing that the $\delta^{13} \mathrm{C}$ values are mostly depleted in planar and cross stratified facies without much depletion of $\delta^{18} \mathrm{O}$ values in the same samples. Depleted $\delta^{18} \mathrm{O}$ values of the stromatolite facies are possibly caused by diagenetic resetting by isotopically lighter fluids. Paleogeography of the stromatolite facies varies considerably and allows the carbonates to interact with pore fluids of different compositions. The stromatolite facies thus exhibits maximum scatter of data points out of the three facies. In plane laminated mudstone facies occurrence of enriched $\delta^{18} \mathrm{O}$ values could be due to the dolomitization effect (Land 1980). All the samples belonging to the planar and cross stratified facies plot outside and a few samples from stromatolite facies and plane laminated mudstone facies plot inside the primary box of Ray et al (2003). It can be mentioned that meteoric diagenetic alteration of isotope values is already anticipated for the samples of planar and cross stratified facies based on paleogeographic setting and their effect on isotope ratios. Plot of the data points of the planar and cross stratified facies outside the 'primary box' further supports the concept of altered isotope signature within the facies.

\section{Conclusions}

The carbonate facies of the Vindhyan Supergroup represents a wide spectrum of depositional processes. Supratidal, shoreface, intertidal, shallow subtidal, lagoonal, estuarine, inner and outer shelf carbonates characterise wide variations in facies and paleogeography. Carbon and oxygen isotope compositions of the constituent facies of the different carbonate units frequently form clusters of data points with moderate to negligible overlap. Original carbon and oxygen isotope compositions of many of the carbonate samples are altered because of diagenetic resetting by isotopically lighter fluids. However, carbon and oxygen isotope compositions of the Rohtas Limestone possibly remained unaltered because depositional substrate was not exposed to allow percolation of meteoric fluids through the carbonate sediments. On the contrary, most of the samples of Kajrahat Limestone (intertidal to supratidal origin) represent depleted $\delta^{18} \mathrm{O}$ values possibly because of diagenetic resetting by isotopically lighter fluids. Scatter of the data points in the latter possibly relates to duration of exposure of the depositional substrata. Both $\delta^{13} \mathrm{C}$ and $\delta^{18} \mathrm{O}$ values of the other two carbonate units, namely Bhander Limestone and Fawn Dolostone have been altered considerably because of meteoric diagenetic effect. Besides the depositional setting, mineralogy of the carbonates are also responsible for the observed scatter in the data points and formation of clusters; elevated $\delta^{18} \mathrm{O}$ values have been noticed in a few facies consisting essentially of dolomites. Stable isotope compositions possibly remain close to primary values when early diagenesis takes place in marine setting, e.g., in the case of Rohtas Limestone. Chemostratigraphic significance of carbon and oxygen data is thus reduced in the case of very shallow marine carbonates, which are likely to be flushed by meteoric water. Our interpretations regarding near primary and altered isotope signatures match closely with the inferences drawn by Ray et al (2003).

\section{Acknowledgements}

Authors are thankful to P K Bose of Jadavpur University for his constant encouragement. We thank Mr. R A Jani for help in isotope analysis. The authors are thankful to Graham Shields and Karem Azmy for their critical comments and suggestions on an earlier version of the manuscript. SB is thankful to the Department of Science and Technology, Govt. of India for financial support.

\section{References}

Auden J B 1933 Vindhyan sedimentation in Son valley; Geol. Surv. India Memoir 62 141-150. 
Banerjee S 1997 Facets of the Mesoproterozoic Semri Sedimentation in Son valley, India. Unpubl. Ph.D. thesis, Jadavpur University, Kolkata, 137 p.

Banerjee S, Sarkar S, Bhattacharyya S K 2005 Facies, dissolution seams and stable isotope characteristics of the Rohtas Limestone (Vindhyan Supergroup) in the Son valley area, central India; J. Earth Sys. Sci. 114 87-96.

Beeunas M A and Knauth L P 1985 Preserved stable isotope signature of subaerial diagenesis in the 1.2 b.y. Mescal Limestone, central Arizona: implication for the timing and development of a terrestrial land plant cover; Geol. Soc. Am. Bull. 96 737-745.

Bose P K, Sarkar S, Chakraborty S and Banerjee S 2001 Overview of the Meso- to Neoproterozoic evolution of the Vindhyan basin, central India; Sedim. Geol. 141 395-419.

Booler J and Tucker M E 2002 Distribution and geometry of facies and early diagenesis: the key to accommodation space variation and sequence stratigraphy: upper Cretaceous Congost carbonate ramp, Spanish Pyrenees. Sedim. Geol. 146 225-247.

Chakraborty P P, Sarkar A, Bhattacharyya S K and Sanyal P 2002 Isotopic and sedimentologic clues to productivity changes in the Late Riphean sea: a case study of two intracracratonic basins of India; Proc. Indian Acad. Sci. (Earth Planet. Sci.) 111(4) 379-370.

Chakraborty P P 2004 Facies architecture and sequence development in a Neoproterozoic carbonate ramp: Lakheri Limestone Member, Vindhyan Supergroup, Central India; Precamb. Res. 132 29-53.

Chanda S K and Bhattacharyya A 1982 Vindhyan sedimentation and paleogeography: post-Auden developments. In: Geology of Vindhyanchal (eds) K S Valdiya, S B Bhatia and V K Gaur (Delhi: Hindusthan Publishing Corporation), pp. 88-101.

Craig H 1957 Isotopic standards for each carbon and oxygen correlation factors for mass spectrometric analysis of carbon dioxide; Geochim. Cosmochim. Acta 12 133-149.

De Raaf J F M, Boersma J R and Vangelder A 1977 Wavegenerated structures and sequences from a hallow marine succession, Lower carboniferous County Cork, Ireland; Sedimentology 24 451-483.

Des Marais D J 1994 Tectonic control of the crustal organic carbon reservoir during the Precambrian; Chem. Geol. 114 303-314.

Dickson J A D 1966 Carbonate identification and genesis as revealed by staining; J. Sedim. Petrol. 36 491-505.

Frank T D, Lyons T W and Lohmann K C 1997 Isotopic evidence for paleoenvironmntal evolution of the Mesoproterozoic Helena Formation (Belt Supergroup, Montana); Geochim. Cosmochim. Acta 61 5023-5041.

Friedman G M and Chakraborty C 1997 Stable isotopes in marine carbonates: Their implications for the paleoenvironment with special reference to the proterozoic Vindhyan carbonates (central India); J. Geol. Soc. India 50 $131-159$

Friedman G M, Chakraborty C and Kolkas M M 1996 Excursion in the end-Proterozoic strata of the Vindhyan basin (central India): its chronostratigraphic significance; Carbonates and Evaporites 11 206-212.

Friedman G M, Chakraborty C and Kolkas M M $2004 \delta^{13} \mathrm{C}$ excursion in the end-Proterozoic strata of the Vindhyan basin; Carbonates and Evaporites 17 206-212.

Glumac B and Walker K R 1997 Selective dolomitisation of Cambrian microbial carbonate deposits: a key to mechanisms and environments of origin; Palaios 12 98-110.

Glumac B and Walker K R 2000 Carbonate deposition and sequence stratigraphy of the terminal Cambrian grand cycle in the southern Applachians, USA; J. Sed. Res. 70 952-963.
Grotzinger J P 1986 Cyclicity and paleoenvironmnetal dynamics, Rocknest platform, northwest Canada; Bull. Geol. Soc. Am. 97 1208-1231.

Hall S M and Veizer J 1996 Geochemistry of Precambrian carbonates. VII. Belt Supergroup, Montana and Idaho, U.S.A; Geochim. Cosmochim. Acta 60 667-977.

Hoffman P F 1976 Environmental diversity of middle Precambrian stromatolites. In: Stromatolites (ed.) Walter M R (Amsterdam: Elsevier) pp. 599-611.

Joachimsky M M 1994 Subaerial exposure and deposition of shallowing upward sequences: evidence from stable isotopes of Puerbeckian peritidal carbonates (basal Cretaceous), Swiss and French Jura mountains; Sedimentology 41 805-824.

Kaufman A J, Knoll A H and Awramik S M 1992 Biostratigraphic and chronostratigraphic correlation of Neoproterozoic sedimentary successions: Upper Tindir Group, northwestern Canada, as a test case; Geology 20 181-185.

Kaufman A J and Knoll A H 1995 Neoproterozoic variations in the C-isotopic compositions of the seawater: stratigraphic and biogeochemical implications; Precamb. Res. $7327-49$.

Knoll A H, Hayes J M, Kaufman A J, Swett K and Lambert I B 1986 Secular variations in carbon isotope ratios from Upper Proterozoic successions of Svalbard and East Greenland; Nature 321 832-838.

Knoll A H, Kaufman A J and Semikhatov M A 1995 The carbon isotopic composition of Proterozoic carbonates of Riphean successions from northwestern Siberia (Anabar Massif, Turukhansk Uplift). Am. J. Sci. 295 823-850.

Kumar B, Das Sharma S, Sreenivas B, Dayal A M, Rao M N, Dubey N and Chawla B R 2002 Carbon, oxygen and strontium isotope geochemistry of Proterozoic carbonate rocks of the Vindhyan basin, central India; Precamb. Res. $11343-63$.

Land L S 1980 The isotopic and trace element geochemistry of dolomite: the state-of-the-art; SEPM Spec. Publ. $\mathbf{2 8}$ 87-110.

Lindsay J F and Brasier M D 2000 A carbon isotope reference curve for 1700-1575 Ma, Mc Arthur and Mt Isa Basins, northern Australia; Precamb. Res. 99 271-308.

Melezhik V A, Fallick A E and Pokrovskyn B G 2005 Enigmatic nature of thick sedimentary carbonates depleted in ${ }^{13} \mathrm{C}$ beyond the canonical mantle value: The challenges to our understanding of the terrestrial carbon cycle; Precamb. Res. 137 131-165.

Prakas R and Dalela K 1982 Stratigraphy of the Vindhyan in Uttar Pradesh: a brief review; In: Geology of Vindhyanchal (eds) Valdiya K S, Bhatia S B and Gaur V K (Delhi: Hindusthan Publishing Corporation), pp. $55-79$.

Rasmussen B, Bose P K, Sarkar S, Banerjee S, Fletcher I R and Mc Naughton N J 2002 1.6 Ga U-Pb zircon ages for the Chorhat Sandstone, Lower Vindhyan, India: possible implication for early evolution of animals; Geology $\mathbf{3 0}$ 103-106.

Ray J S, Martin M W and Veizer J 2002 U-Pb zircon dating and Sr isotope systematics of the Vindhyan Supergroup, India; Geology 30 131-134.

Ray J S, Veizer J and Davis W J 2003 C, O, Sr and Pb isotope systematics of carbonate sequences of the Vindhyan Supergroup, India: age, diagenesis, correlation and implications for global events; Precamb. Res. 121 103-140.

Sarangi S, Gopalan K and Kumar S $2004 \mathrm{~Pb}-\mathrm{Pb}$ age of earliest megascopic eukaryotic alga bearing Rohtas Formation, Vindhyan Supergroup, India: Implications for Precambrian atmospheric oxygen evolution; Precamb. Res. 132 107-121. 
Sarkar S, Chakraborty P P and Bose P K 1996 Proterozoic Lakheri Limestone, central India: facies, paleogeography and physiography; In: Recent Advances in Vindhyan Geology (ed.) Bhattacharyya A, Geol. Soc. India Memoir 36 5-25.

Sarkar S, Chakraborty P P, Bhattacharya S and Banerjee S 1998 C-12 enrichment along intraformational unconformities within Proterozoic Bhander Limestone and its implications, Son valley, India; Carbonates and Evaporites 13 108-114.

Schieber J 1999 Microbial mats in terrigenous clastics: the challenge of identification in the rock record; Palaios $\mathbf{1 4}$ $3-12$.
Shields G and Veizer J 2002 Precambrian marine isotope database: version 1.1; Geochem. Geophys. Geosys. 3 U1-U12.

Southgate P N 1989 Relationship between cyclicity and stromatolite form in the Proterozoic Bitter Springs Formation, Australia; Sedimentology 36 323-329.

Veizer J, Holser W T and Wilgus C K 1980 Correlation of ${ }^{13} \mathrm{C} /{ }^{12} \mathrm{C}$ and ${ }^{34} \mathrm{~S} /{ }^{32} \mathrm{~S}$ secular variations; Geochim. Cosmochim. Acta 44 579-587.

Veizer J, Plum K A, Clayton R N, Hinton R W and Grotzinger J P 1992 Geochemistry of Precambrian carbonates: V. Late Paleoproterozoic seawater; Geochim. Cosmochim. Acta 56 2487-2501. 